\title{
Petrologia do Stock Serra da Vaca, Domínio Poço Redondo, Sistema Orogênico Sergipano
}

\author{
Petrology of Serra da Vaca Stock, Poço Redondo Domain, Sergipano Orogenic System
}

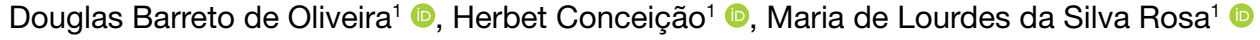 \\ ${ }^{1}$ Universidade Federal de Sergipe - UFS, Programa de Pós-Graduação em Geociências e Análise de Bacias - PGAB, \\ Laboratório de Petrologia Aplicada à Pesquisa Mineral, Avenida Marechal Rondon, s/n, Jardim Rosa Elze, CEP: 49100-000, \\ São Cristóvão, SE, BR (dbogeo@gmail.com; herbet@academico.ufs.br; Irosa@academico.ufs.br)
}

Recebido em 13 de outubro de 2019; aceito em 10 de maio de 2021.

\begin{abstract}
Resumo
O Stock Serra da Vaca (SSV, $19 \mathrm{~km}^{2}$ ) é alongado NE-SW e localiza-se no norte do Domínio Poço Redondo, no Sistema Orogênico Sergipano. A orientação desse stock trunca a foliação metamórfica regional NW-SE. O SSV é constituído por biotita granodioritos leucocráticos de cor cinza, textura equigranular fina a média e têm estrutura maciça. Sienogranitos e álcali-feldspato granito são presentes. Os minerais acessórios dessas rochas são epídoto, zircão, apatita e minerais opacos. O feldspato alcalino é pertítico. Andesina e oligoclásio dos granodioritos apresentam zonação normal, indicativa de cristalização fracionada. A biotita marrom é primária, tem razão $\mathrm{Fe} /(\mathrm{Fe}+\mathrm{Mg})$ variando de $0,47-0,84$ e exibe afinidade química com suítes cálcio-alcalinas. O epídoto primário $(19,9<\%$ pistacita $<28,85)$ indica cristalização em condições relativamente oxidantes a pressão de $6 \mathrm{kbar}(\sim 25 \mathrm{~km})$. Os dados geoquímicos indicam que as rochas do SSV são evoluídas $\left(70 \%<\mathrm{SiO}_{2}<77,5 \%\right)$, peraluminosas e magnesianas. A filiação magmática dos granodioritos é cálcio-alcalina de alto $\mathrm{K}$, enquanto os sienogranitos apresentam afinidade shoshonítica. As razões $(\mathrm{La} / \mathrm{Yb})_{\mathrm{N}}$ variam de 21-70 nos granodioritos, 40 no álcali-feldspato granito e 1,4-2,8 nos sienogranitos. As anomalias de Eu são pouco pronunciadas para a maioria das amostras $\left(0,57<\mathrm{Eu} / \mathrm{Eu}^{*}<0,94\right)$, à exceção do álcali-granito e dos sienogranitos, que exibem forte anomalia negativa em európio $(0,16-0,30)$. Os dados químicos de elementos maiores sugerem que o magma SSV tenha se formado a partir de protólitos ígneos máficos e potássicos. As relações entre elementos-traço (e.g. Th, Ta, Hf, Y, Nb, $\mathrm{Rb}$ ) indicam que esses granitos foram gerados em ambiente orogênico em período pós-tectônico. Sugere-se que os granodioritos do SSV pertençam à Suíte Intrusiva Coronel João Sá do Domínio Macururé, uma vez que apresentam assinatura geoquímica de magmas máficos potássicos, pós-colisionais e intrusivos em ambiente de arco vulcânico com assinatura de fluidos de subducção.
\end{abstract}

Palavras-chave: Stock Serra da Vaca; Granito Orogênico; Sergipe; Província Borborema.

\begin{abstract}
Serra da Vaca Stock (SSV, $19 \mathrm{~km}^{2}$ ) is elongated NE-SW, located in the North of Poço Redondo Domain, in the Sergipano Orogenic System. The orientation of this stock cut off the NW-SE regional metamorphic foliation. SVS is composed of biotite gray leucocratic granodiorites of gray color, fine to medium equigranular texture, of isotropic structure. Syenogranites and alkali-feldspar granite are present. The accessory minerals of these rocks are epidote, zircon, apatite, and opaque minerals. Alkaline feldspar is perthitic. Andesine and oligoclase of granodiorites have normal zonation, indicating fractional crystallization. Brown biotite is primary and has $\mathrm{Fe} /(\mathrm{Fe}+\mathrm{Mg})$ ratio ranging from $0.47-0.84$ and exhibits chemical affinity for calcalkaline suites. The primary epidote $(19.9<\%$ pistacite $<28.85)$ indicates crystallization under relatively oxidizing conditions at a pressure of $6 \mathrm{kbar}(\sim 25 \mathrm{~km})$. Geochemical data indicate that SVS rocks are evolved $\left(70 \%<\mathrm{SiO}_{2}<77.5 \%\right)$, peraluminous and magnesian. The magmatic affiliation of granodiorites is high $\mathrm{K}$ calc-alkaline, whereas syenogranites, which are the most evolved, have shoshonitic affinity. The $(\mathrm{La} / \mathrm{Yb})_{\mathrm{N}}$ ratios range from $21-70$ of granodiorites, 40 in the alkali granite, and 1.4-2.8 in the sienogranites. Eu anomalies are poorly pronounced for most samples $(0.57<\mathrm{Eu} / \mathrm{Eu} * 0.94)$, except for alkali-granite and syenogranites, which exhibit a strong europium negative anomaly (0.16-0.3). Data on trace elements suggest that SVS magma was formed from potassium mafic igneous protoliths. Relations between trace elements (e.g., Th, Ta, $\mathrm{Hf}, \mathrm{Y}, \mathrm{Nb}, \mathrm{Rb}$ ) indicate that these granites were generated in an orogenic environment in a post-tectonic period. SSV granodiorites are suggested to belong to the Coronel João Sá Intrusive Suite of the Macururé Domain, since they have a geochemical signature of potassic, post-collisional, and intrusive magmatic magmas in a volcanic arch, with the signature of subduction fluids.
\end{abstract}

Keywords: Serra da Vaca Stock; Orogenic Granite; Sergipe; Borborema Province. 


\section{INTRODUÇÃO}

A Província Borborema (Almeida et al., 1977), localizada no Nordeste brasileiro, tem área de aproximadamente 450.000 $\mathrm{km}^{2}$ e sua origem, segundo Van Schmus et al. (2008), é relacionada a eventos de convergência (ca. $600 \mathrm{Ma}$ ) de blocos do Oeste da África, do Congo-São Francisco e da Amazônia. Van Schmus et al. (2011) dividem a Província Borborema em três subprovíncias: norte, central e sul.

Na subprovíncia sul tem-se o Maciço Pernambuco-Alagoas e o Sistema Orogênico Sergipano (SOS). Esse orógeno, anteriormente denominado de Faixa Sergipana, foi objeto de estudo de vários pesquisadores durante as décadas de $1960 \mathrm{e}$ 1970 (e.g. Humphrey e Allard, 1967; Silva Filho et al., 1979) e em anos recentes (e.g. Oliveira et al., 2010, 2015, 2017; Conceição et al., 2017). Os resultados dessas pesquisas permitiram identificar que a evolução do SOS é de complexa história geológica (Oliveira et al., 2010, 2017) que resultou da formação da parte ocidental do supercontinente Gondwana.

O SOS é interpretado como um orógeno neoproterozoico resultante da colisão entre o Cráton São Francisco e o Maciço Pernambuco-Alagoas há aproximadamente 600 Ma (Brito Neves et al., 1977; Oliveira et al., 2010, 2015). Bueno et al. (2009) argumentam, com base em datações $\mathrm{U}-\mathrm{Pb}_{\text {Shrimp }}$ em granitos, que a orogenia que formou o SOS durou $57 \mathrm{Ma}(628-571 \mathrm{Ma})$.

Uma feição importante no SOS é a presença de granitos ediacaranos (e.g. Long et al., 2005; Bueno et al., 2009; Oliveira et al., 2015; Conceição et al., 2017; Lisboa et al., 2019). O desenvolvimento de pesquisas recentes e sistemáticas em granitos do SOS (e.g. Conceição et al., 2016; Lisboa et al., 2019; Pinho Neto et al., 2019; Santos et al., 2019; Soares et al., 2018, 2019; Sousa et al., 2019) aportaram novas informações geológicas, petrográficas, mineraloquímicas e idades. Embora tenha-se avançado bastante, ainda existem várias intrusões graníticas carentes de dados sistemáticos de geologia, petrografia, mineraloquímica, geoquímica e geocronologia.

Este trabalho apresenta e discute os primeiros dados petrográficos, de química mineral e geoquímica das rochas que compõem o Stock Serra da Vaca (SSV), que é uma intrusão localizada no Domínio Poço Redondo (DPR), norte do SOS. Nesse contexto, comparam-se os dados obtidos do SSV com os de outros corpos graníticos do DPR, bem como de rochas migmatíticas encaixantes, de forma a se investigar a possibilidade de derivação do SSV a partir da fusão parcial desses migmatitos.

\section{CONTEXTO REGIONAL}

O SOS é formado por faixas que têm orientação ESE-WNW e não se limitam a Sergipe, mas ocorreram igualmente nos estados de Alagoas e da Bahia (Figura 1; Brito Neves et al., 1977; Oliveira et al., 2017). As faixas que formam o SOS correspondem a terrenos com características geológicas distintas e são limitadas por zonas de cisalhamento (Davison e Santos, 1989). Esses domínios geológicos identificados por Davison e Santos (1989), Mendes et al. (2011) e Neves et al. (2016) foram nomeados de: Estância, Vaza-Barris, Macururé, Marancó, Poço Redondo, Canindé e Rio Coruripe.

Os domínios meridionais (Estância e Vaza-Barris) são formados por rochas metassedimentares fracamente deformadas a baixo grau metamórfico (Davison e Santos, 1989; Oliveira et al., 2010). O Domínio Macururé ocorre na porção central do SOS, compreende rochas metassedimentares, deformadas e submetidas às condições fácies anfibolito, e várias intrusões graníticas (e.g. Davison e Santos, 1989; Bueno et al., 2009; Conceição et al., 2016). O Domínio Marancó é composto por rochas vulcanossedimentares metamorfisadas nas fácies xisto verde e anfibolito bem como por granitos (Santos et al., 1988; Carvalho, 2005; Oliveira et al., 2015). O Domínio Canindé é formado por rochas metavulcanossedimentares, complexos máfico-ultramáficos, diques máficos e félsicos (Davison e Santos, 1989; Oliveira et al., 2010). O Domínio Rio Coruripe, localizado na parte norte do SOS, é constituído por rochas supracrustais e granitos de composições variadas (Lima, 2013).

A área deste estudo localiza-se no DPR, porção norte do SOS (Figura 2). O DPR é o único subdomínio do SOS que tem migmatitos. A presença desses migmatitos foi utilizada por Santos et al. (1988) e Carvalho (2005) para inferir que o DPR representa o nível crustal mais profundo no SOS.

O DPR faz contato tectônico ao sul com o Domínio Marancó e ao norte com o Domínio Canindé pela Zona de Cisalhamento Macururé (Figura 2). Ele é composto pelo Complexo Migmatítico Poço Redondo e por várias intrusões graníticas (Santos et al., 1988; Davison e Santos, 1989; Carvalho, 2005; Oliveira et al., 2015; Sousa et al., 2019; Pinho Neto et al., 2019).

Carvalho (2005) classifica os migmatitos do DPR como sendo granodioritos cálcio-alcalinos e os interpreta como a crosta de um arco magmático. Esse mesmo autor obteve ida-

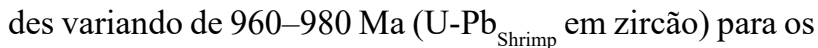
paleossomas dos migmatitos e interpreta essas idades como o período de cristalização dos protólitos magmáticos. A idade $\mathrm{T}_{\mathrm{DM}}$ de 1,48 associada a valores $\varepsilon_{\mathrm{Nd}}$ fracamente negativos e positivos dos migmatitos levaram Carvalho (2005) a interpretar que essas rochas são formadas no Mesoproterozoico a partir de protólito mantélico.

No DPR ocorrem intrusões graníticas ediacaranas com dimensões variadas (Santos et al., 1988; Davison e Santos, 1989; Carvalho, 2005; Oliveira et al., 2015; Sousa et al., 2019). Segundo Teixeira et al. (2014), no DPR ocorrem cinco das suítes intrusivas presentes no SOS: Sítios Novos, Serra do Catu, Coronel João Sá, Queimada Grande e Glória-Xingó 2. 


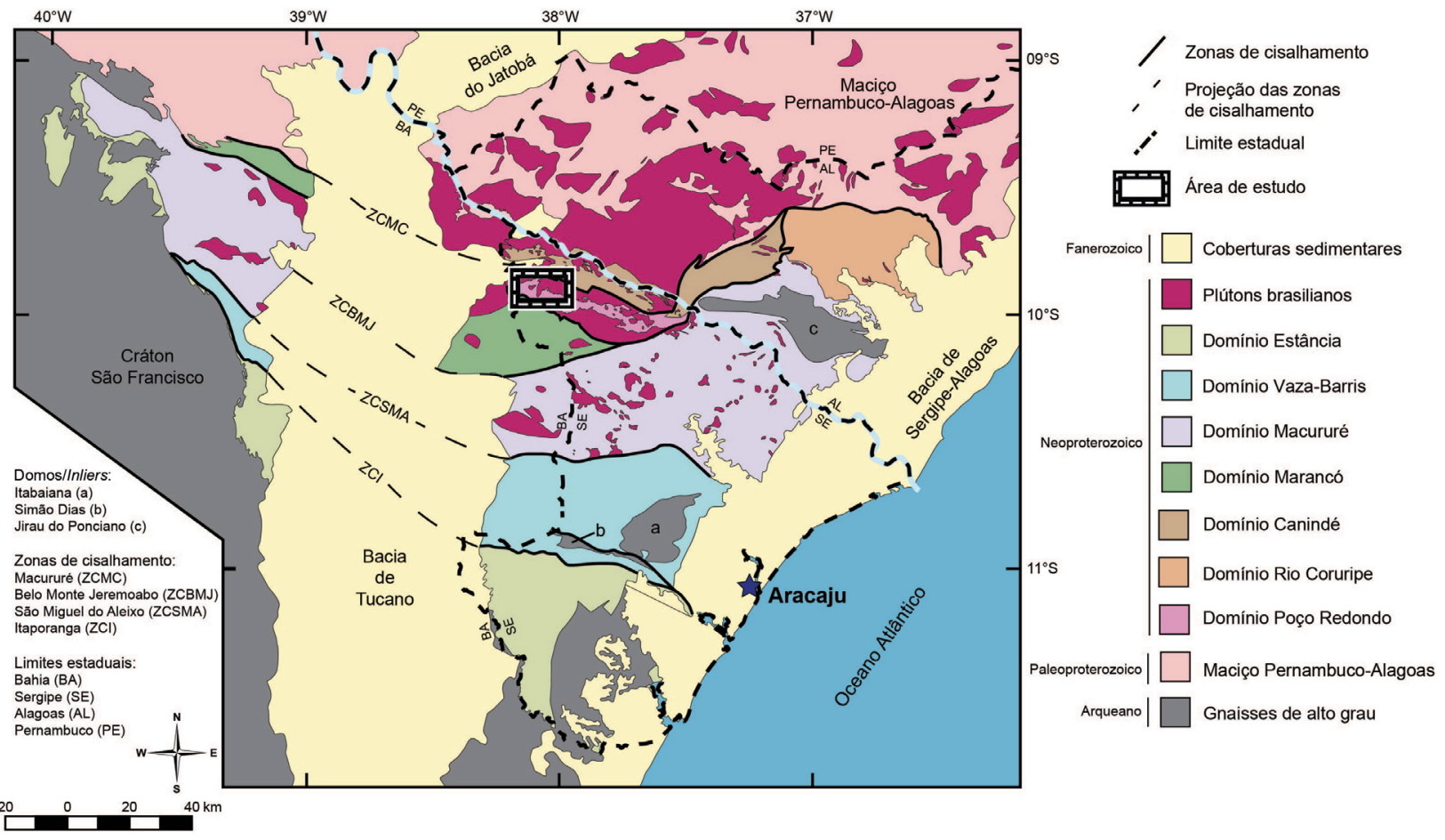

Figura 1. Esquema geológico da parte sul da Província Borborema, segundo a compilação elaborada por Pinho Neto et al. (2019).

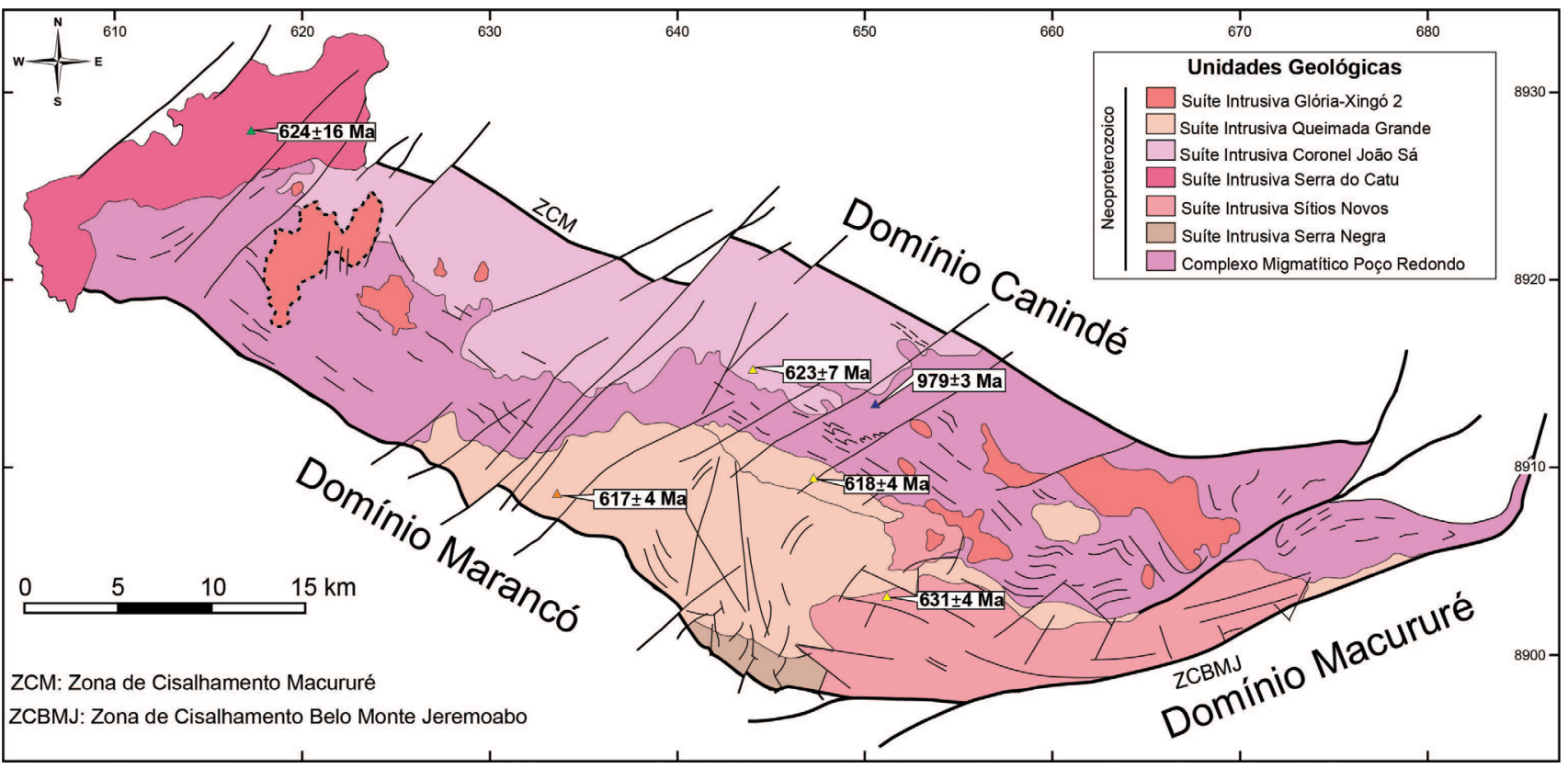

Figura 2. Esquema geológico do Domínio Poço Redondo segundo Teixeira et al. (2014). O Stock Serra da Vaca, objeto deste estudo, tem contorno destacado por linha tracejada. Apresenta-se o valor das idades absolutas $U-\mathrm{Pb}_{\text {Shrimp }}$ obtidas em cristais de zircão disponíveis na literatura para corpos das diferentes suítes intrusivas no Domínio Poço Redondo (Oliveira et al., 2015; Lima, 2016; Sousa et al., 2019). A idade do migmatito de $979 \pm 3$ Ma foi obtida por Carvalho (2005). 
A maioria dos granitos dessas suítes (e.g. Queimada Grande, Sítios Novos, Coronel João Sá) segue a orientação regional NW-SE do DPR, sugerindo que a deformação regional influenciou o alojamento desses magmas (Figura 2). Os corpos da Suíte Glória-Xingó 2, diferentemente das demais suítes intrusivas, ocorrem como diques e estão relacionados às falhas tardias NE-SW do SOS (Santos et al., 1988; Carvalho, 2005). O Batólito Curituba, entretanto, representante da Suíte Serra do Catu, trunca as zonas de cisalhamento NW-SE (Figura 2), indicando que a sua intrusão foi posterior à estruturação das zonas de cisalhamento.

Os dados geocronológicos $\left(\mathrm{U}^{-} \mathrm{Pb}_{\text {Shrimp }}\right)$ disponíveis para o magmatismo no DPR (Oliveira et al., 2015; Lima, 2016; Sousa et al., 2019) evidenciam que esse plutonismo foi ativo durante $14 \mathrm{Ma}$ (617-631 Ma), posicionando-se durante a fase pré-colisional no evento que formou o SOS (Bueno et al., 2009; Oliveira et al., 2015, 2017).

O SVV, objeto deste estudo, é associado por Teixeira et al. (2014) ao magmatismo da Suíte Intrusiva Glória-Xingó 2. Essa suíte é descrita como constituída por leucogranitos peraluminosos com muscovita ou biotita contendo granada ou turmalina. A realização de trabalhos em escala de detalhe em corpos dessa suíte (e.g. Gouveia, 2016; Oliveira, 2016) identificou que as rochas da Suíte Intrusiva GlóriaXingó 2, no DPR, apresentam composições granodioríticas e monzograníticas e são desprovidas de granada ou turmalina, sendo a biotita o mineral máfico dominante. Os dados geoquímicos apresentados por Gouveia (2016) e Oliveira (2016) evidenciam que as rochas da Suíte Intrusiva GlóriaXingó 2, no DPR, são fortemente evoluídas $\left(\mathrm{SiO}_{2}>71 \%\right)$, peraluminosas e apresentam afinidades geoquímicas com as séries magmáticas cálcio-alcalina de alto $\mathrm{K}$ e shoshonítica, além de exibirem assinatura de granitos de arco vulcânico.

\section{MATERIAIS E MÉTODOS}

Para este estudo, foram descritos 21 afloramentos nos quais coletaram-se 14 amostras representativas. As 14 rochas foram laminadas e as descrições microscópicas foram feitas com microscópios petrográfico (luz transmitida e refletida) e eletrônico de varredura (MEV), utilizando-se, neste último, o detector de elétrons retroespalhados (BSE = Backscattered Electrons).

A moda das rochas foi estabelecida com base na estimativa visual de 40 campos em cada lâmina. A nomenclatura das rochas seguiu as recomendações de Le Maitre et al. (2002). Após a petrografia, as lâminas foram metalizadas com ouro, para posterior análise com os detectores BSE no MEV. As análises químicas pontuais dos minerais foram obtidas com espectrômetro de energia dispersiva (EDS) da marca Oxford Instruments ${ }^{\circledR}$, modelo X-act, acoplado a um ao MEV (Tescan, modelo LMU), do Condomínio de
Laboratórios Multiusuários das Geociências da Universidade Federal de Sergipe (UFS).

As condições de operação do MEV neste estudo foram: aceleração de $20 \mathrm{kV}$, corrente de $17 \mathrm{nA}$, feixe de elétrons com diâmetro de $0,4 \mu \mathrm{m}$ e tempo de contagem médio de 30 segundos. As correções utilizadas na quantificação dos dados químicos foi a $\mathrm{ZAF}$ ( $\mathrm{Z}=$ número atômico, $\mathrm{A}=$ absorbância e $\mathrm{F}$ = fluorescência). A composição química pontual dos cristais foi obtida utilizando-se do software Quant, da Oxford Instruments ${ }^{\circledR}$. As avaliações dos resultados químicos foram feitas com análises de padrões internacionais de minerais da Artimex (silicatos e óxidos). Os cálculos das fórmulas estruturais dos minerais analisados foram realizados utilizando-se as recomendações de Deer et al. (1992).

A preparação física das amostras de rocha para a realização das análises geoquímicas foi feita no Departamento de Geologia da Universidade Federal de Sergipe. O peso das amostras utilizadas na preparação variou de $1-3 \mathrm{~kg}$. A brita foi obtida com britador de mandíbula de marca Pavitest (I-4198), obtendo-se fragmentos de rocha com dimensões inferiores a $1,5 \mathrm{~cm}$. Cerca de $200 \mathrm{~g}$ de brita foram obtidos por quarteamento para a confecção do pó. Obteve-se o pó, com granulação inferior a 200 mesh, utilizando-se moinho com panela de tungstênio da maraca Pavitest (I-4227).

As análises químicas dos elementos maiores foram obtidas no CLGeo-UFS por fluorescência de raios X, utilizando-se o equipamento Shimadzu $1800^{\circledR}$, pelo método do pó prensado, e a perda ao fogo foi obtida pela calcinação da amostra a $1.000^{\circ} \mathrm{C}$. Os elementos-traço foram dosados unicamente nas rochas do SSV. As análises dos elementos-traço foram dosados por ICP-MS (inductively coupled plasma mass spectrometry), após fusão multiácida das amostras, no laboratório comercial da Geosol S.A., em Minas Gerais.

\section{GEOLOGIA LOCAL}

\section{Stock Serra da Vaca}

O SSV $\left(19 \mathrm{~km}^{2}\right)$ é uma intrusão orientada NNE-SSW (Figura 3). O relevo, nessa região, é caracterizado pela presença de morros esparsos cujas cotas chegam a até $400 \mathrm{~m}$. Os contatos com as rochas encaixantes são de difícil visualização em campo. Todavia, utilizando-se de fotografias áreas, foi possível inferir os contatos com os terrenos do Complexo Migmatítico Poço Redondo, ao sul, oeste e leste, e com o Batólito Granítico Poço Redondo, ao nordeste (Figura 3). O caráter intrusivo do SSV foi inferido pela presença de xenólitos de migmatitos encaixantes (Figura 4A). As rochas do SSV têm cor clara (esbranquiçada e acinzentada) e granulação fina a média (Figura 4B). A textura dessas rochas é equigranular; contudo, em algumas amostras, tem-se textura inequigranular, com fenocristais de plagioclásio e feldspato alcalino. Por vezes, 


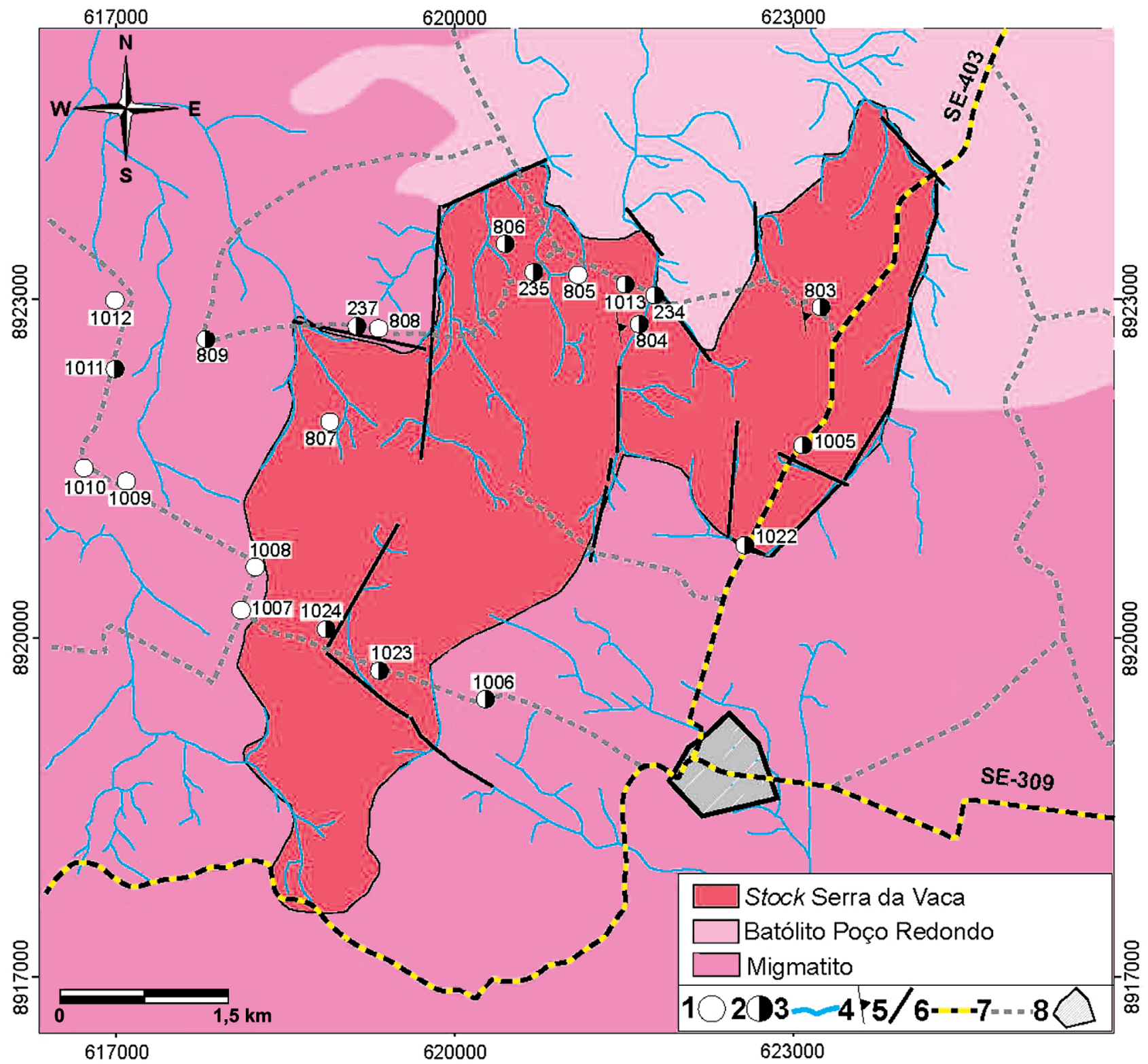

1: ponto visitado; 2: ponto amostrado; 3: drenagens; 4: foliação; 5: fraturas/falhas; 6: rodovia estadual; 7: estrada vicinal; 8: Povoado Capim Grosso no município de Canindé de São Francisco, Sergipe.

Figura 3. Esquema geológico do Stock Serra da Vaca.

percebe-se a presença de foliação magmática orientada NNE-SSW, que é marcada pelo alinhamento dos cristais de biotita. Diques graníticos de granulação fina e coloração creme (Figura 4C) também ocorrem de forma esporádica.

\section{Migmatitos}

Os terrenos do Complexo Migmatítico Poço Redondo na área de estudo são constituídos, predominantemente, por diatexitos. Nessas rochas é possível observar estruturas nebulítica e schlieren. O bandamento e a foliação do migmatito seguem o trend regional NW-SE. O leucossoma tem cor clara, granulação média a grossa, estrutura maciça e textura inequigranular. O paleossoma exibe cor cinza e tem textura inequigranular, com fenoblastos $(0,9-6 \mathrm{~cm})$ de feldspato alcalino dispostos de forma caótica e imersos em matriz de granulação média. Com frequência, têm-se enclaves $(20 \mathrm{~cm}-2 \mathrm{~m})$ de anfibolitos e de gnaisses máficos bandados com foliação discordante daquela presente no migmatito (Figura 4D), o que indica rotação e uma complexa história deformacional. 


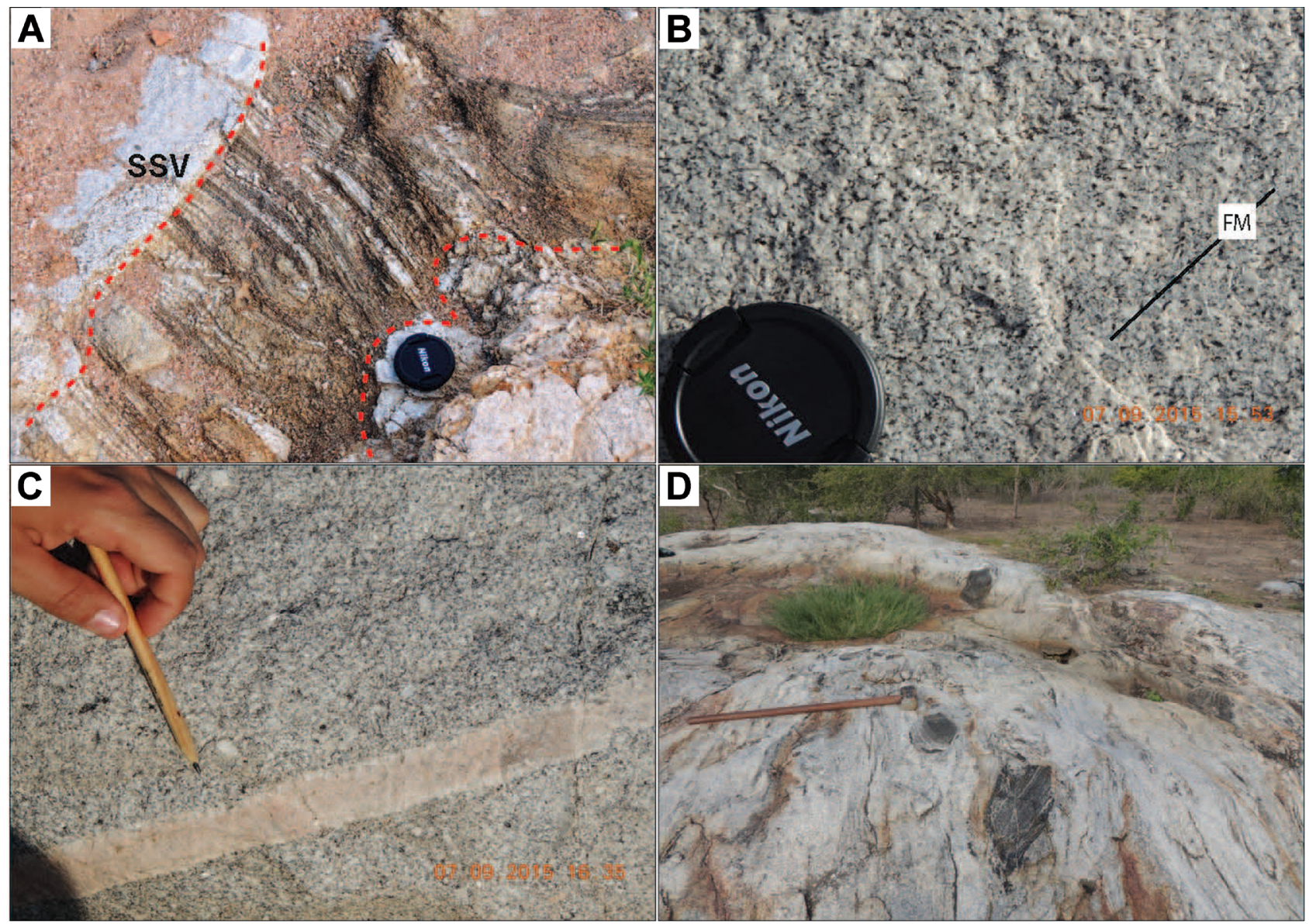

Figura 4. Imagens de afloramentos da região estudada. (A) Xenólito de migmatito (rocha bandada) em granito do Stock Serra da Vaca (SSV). (B) Granito de coloração acinzentada, textura equigranular e com foliação magmática (FM) marcada pelo alinhamento dos cristais de biotita (pontos e traços pretos). (C) Granito inequigranular cortado por dique granito de granulação fina e cor creme. (D) Aspecto da estrutura gnáissica geral observada em afloramentos de migmatitos do Complexo Migmatítico Poço Redondo; a rocha apresenta estrutura gnáissica, exibindo ainda feições nebulíticas e enclaves de gnaisse máfico bandado (centro da imagem) com foliação preexistente transposta pelo bandamento do migmatito encaixante.

\section{PETROGRAFIA E QUÍMICA MINERAL}

Os dados modais das rochas estudadas são apresentados na Tabela 1. As rochas do SSV correspondem, predominantemente, a biotita granodioritos (amostras 234, 235, 804, $806,1005,1013$ e 1022). De forma subordinada, têm-se biotita álcali-feldspato granito (amostra 803) e sienogranitos (amostras 1023 e 1024; Figura 5).

\section{Biotita granodiorito}

Os biotita granodioritos ocorrem nas regiões centro-norte do SSV e predominam no SSV. Essas rochas apresentam coloração acinzentada a esbranquiçada, granulação fina a média, com textura hipidiomórfica equigranular (Figura 6A) e, ocasionalmente, inequigranular.

Os cristais de plagioclásio (Tabela 2; Figura 7A) dos biotita granodioritos correspondem a oligoclásio $\left(\mathrm{An}_{14-29}\right)$ e andesina $\left(\mathrm{An}_{30-49}\right)$. Esses cristais são subédricos, anédricos e têm tamanho em torno de $0,9 \mathrm{~mm}$. Ocorrem geminados albita e albita-Carlsbad (Figura 6B), e com frequência exibem núcleos sericitazados e periferia sem alteração, sugerindo existência de zonação composicional. O tipo de zonação nos cristais de plagioclásio nas rochas do SSV é normal e é mais evidente nos granodioritos (Figura 7B). O plagioclásio inclui, com frequência, cristais de: quartzo; biotita; epídoto com núcleo de allanita e figuras de corrosão (Figura 6F); zircão e apatita. 
Tabela 1. Resultados da análise modal dos granitos do Stock Serra da Vaca e de rochas migmatíticas do Complexo Migmatítico Poço Redondo.

\begin{tabular}{|c|c|c|c|c|c|c|c|c|c|c|c|c|c|c|}
\hline \multicolumn{11}{|c|}{ Stock Serra da Vaca } & \multicolumn{4}{|c|}{ Migmatito } \\
\hline Amostra & 234 & 235 & 803 & 804 & 806 & 1005 & 1013 & 1022 & 1023 & 1024 & 237 & 809 & 1006 & $1011 c$ \\
\hline $\begin{array}{l}\text { Nome da } \\
\text { Rocha }\end{array}$ & $\begin{array}{l}\mathrm{Bt} \\
\mathrm{Grd}\end{array}$ & $\begin{array}{l}\mathrm{Bt} \\
\text { Grd }\end{array}$ & $\begin{array}{c}\mathrm{Bt} \mathrm{Al} \\
\mathrm{Gr}\end{array}$ & $\begin{array}{l}\mathrm{Bt} \\
\mathrm{Grd}\end{array}$ & $\begin{array}{l}\mathrm{Bt} \\
\mathrm{Grd}\end{array}$ & $\begin{array}{l}\mathrm{Bt} \\
\text { Grd }\end{array}$ & $\begin{array}{l}\mathrm{Bt} \\
\text { Grd }\end{array}$ & $\begin{array}{l}\text { Bt } \\
\text { Grd }\end{array}$ & Sgr & Sgr & $\begin{array}{c}\mathrm{Bt} \\
\mathrm{Mzg}\end{array}$ & $\begin{array}{l}\mathrm{Bt} \\
\mathrm{Grd}\end{array}$ & $\begin{array}{c}\text { Bt } \\
\text { Mzg }\end{array}$ & $\begin{array}{l}\text { Bt } \\
\text { Grd }\end{array}$ \\
\hline Plagioclásio & 47,4 & 43,0 & 5,0 & 49,0 & 45,0 & 53,5 & 45,5 & 46,1 & 22,1 & 21,3 & 36,0 & 51,1 & 36,0 & 45,0 \\
\hline Microclina & 16,5 & 15,0 & 67,0 & 22,5 & 23,0 & 16,5 & 20,5 & 21,2 & 43,1 & 47,1 & 33,0 & 15,0 & 30,0 & 5,2 \\
\hline Quartzo & 28,0 & 34,0 & 18,0 & 19,0 & 20,0 & 22,7 & 24,0 & 26,0 & 33,0 & 29 & 25,0 & 20,0 & 31,0 & 25,0 \\
\hline Biotita & 5,4 & 5,8 & 8,9 & 8,5 & 11,0 & 5,5 & 7,5 & 5,1 & 1,3 & 1,4 & 5,1 & 11,2 & & 23,0 \\
\hline Muscovita & 1,5 & 0,9 & 0,3 & 0,3 & 0,4 & 0,3 & 0,2 & 0,3 & & 0,2 & 0,3 & 1,0 & & \\
\hline Epídoto & 0,6 & 0,8 & 0,2 & 0,2 & 0,1 & 0,3 & 0,9 & 0,4 & & 0,2 & 0,2 & & 0,3 & 0,3 \\
\hline Allanita & 0,1 & 0,2 & 0,1 & 0,1 & 0,1 & 0,2 & 0,2 & 0,2 & & 0,1 & 0,1 & & 0,1 & 0,1 \\
\hline M. Opacos & 0,2 & 0,1 & 0,2 & 0,2 & 0,1 & 0,8 & 0,7 & 0,4 & 0,3 & 0,5 & 0,1 & 0,5 & 1,6 & 0,9 \\
\hline Apatita & 0,1 & 0,1 & 0,1 & 0,1 & 0,1 & 0,1 & 0,1 & 0,1 & 0,1 & 0,1 & 0,1 & 0,1 & 0,1 & 0,1 \\
\hline Zircão & 0,1 & 0,1 & 0,1 & 0,1 & 0,1 & 0,1 & 0,1 & 0,1 & 0,1 & 0,1 & 0,1 & 0,1 & 0,1 & 0,1 \\
\hline Titanita & 0,1 & & 0,1 & & 0,1 & & 0,3 & 0,2 & & & & & 0,8 & 0,2 \\
\hline Pirita & & & & & & & & & & & & & & 0,1 \\
\hline
\end{tabular}

Bt Grd: biotita granodiorito; Bt Mzg: biotita monzogranito; Sgr: sienogranito; Bt Al Gr: biotita álcali-feldspato granito.

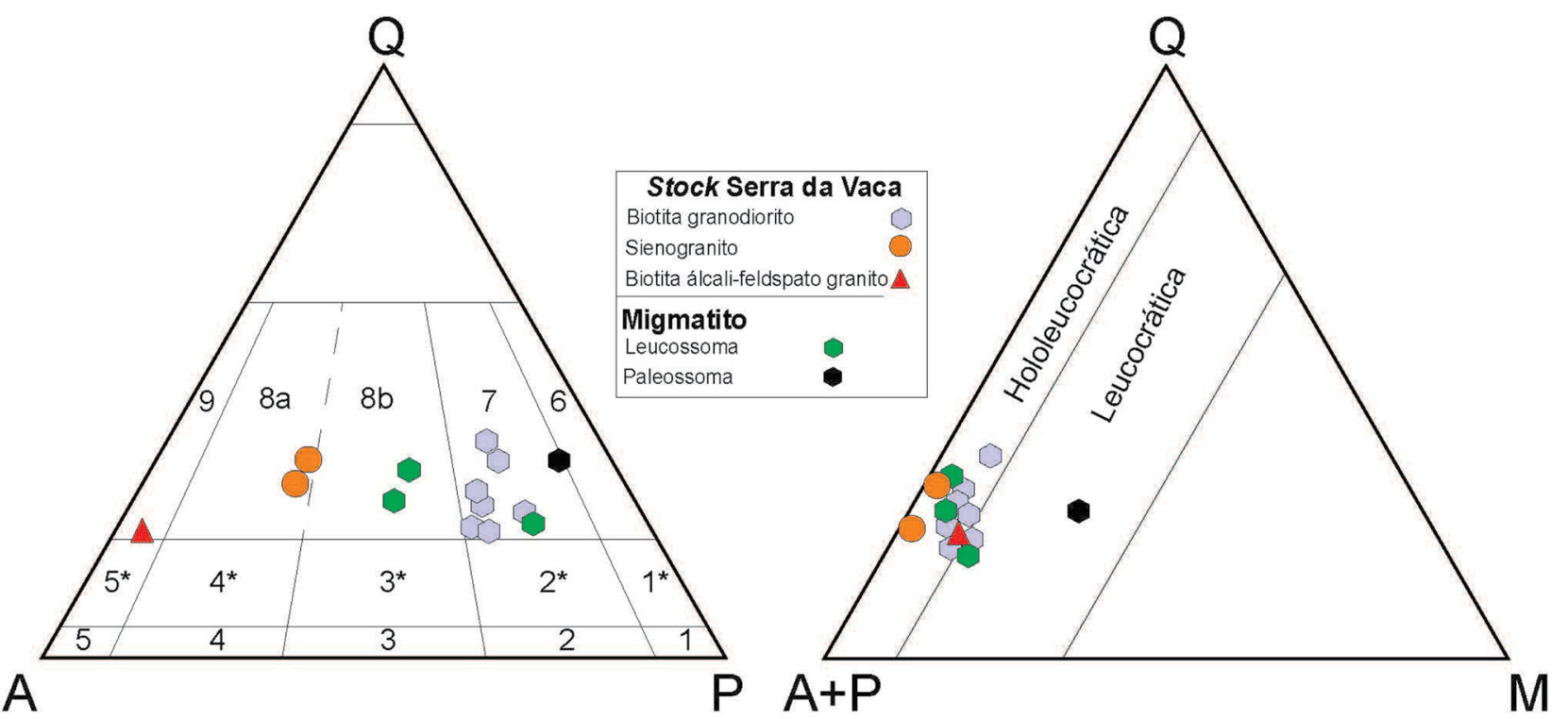

1: diorito; 2: monzodiorito; 3: monzonito; 4: sienito; 5: álcali-feldspato sienito; 6: tonalito; 7: granodiorito; 8a: sienogranito; 8b: monzogranito; 9: álcali-feldspato granito; "variedades de rochas com quartzo; Q: quartzo; A: feldspato alcalino; P: plagioclásio; M: minerais máficos.

Figura 5. Diagramas ternários QAP e Q(A + P)M para classificações de rochas plutônicas, segundo Streckeisen (1976), aplicado às rochas estudadas.

O feldspato alcalino é pertítico, geminado segundo a lei albita-periclina, e, por vezes, percebem-se relíquias da geminação Carlsbad (Figura 6D). Os tamanhos variam de $0,5-10 \mathrm{~mm}$, predominando cristais com $1 \mathrm{~mm}$. É poiquílitico e inclui quartzo, biotita marrom, apatita, epídoto e zircão. As composições das fases exsolvidas são: potássica varia de $\mathrm{Or}_{83} \mathrm{Ab}_{17}$ até $\mathrm{Or}_{98} \mathrm{Ab}_{2}$ e a sódica varia de $\mathrm{Or}_{0,5} \mathrm{Ab}_{98,2} \mathrm{An}_{1,3}$ a $\mathrm{Or}_{0} \mathrm{Ab}_{100} \mathrm{An}_{0}$ (Figura 7A).

O quartzo é anédrico e exibe extinção ondulante em forma de barra forte a moderada. Os tamanhos variam de $0,15-2,85$ $\mathrm{mm}$. Os contatos são curvilíneos a reentrantes com os demais cristais da rocha. Inclui cristais de zircão, apatita e biotita. 

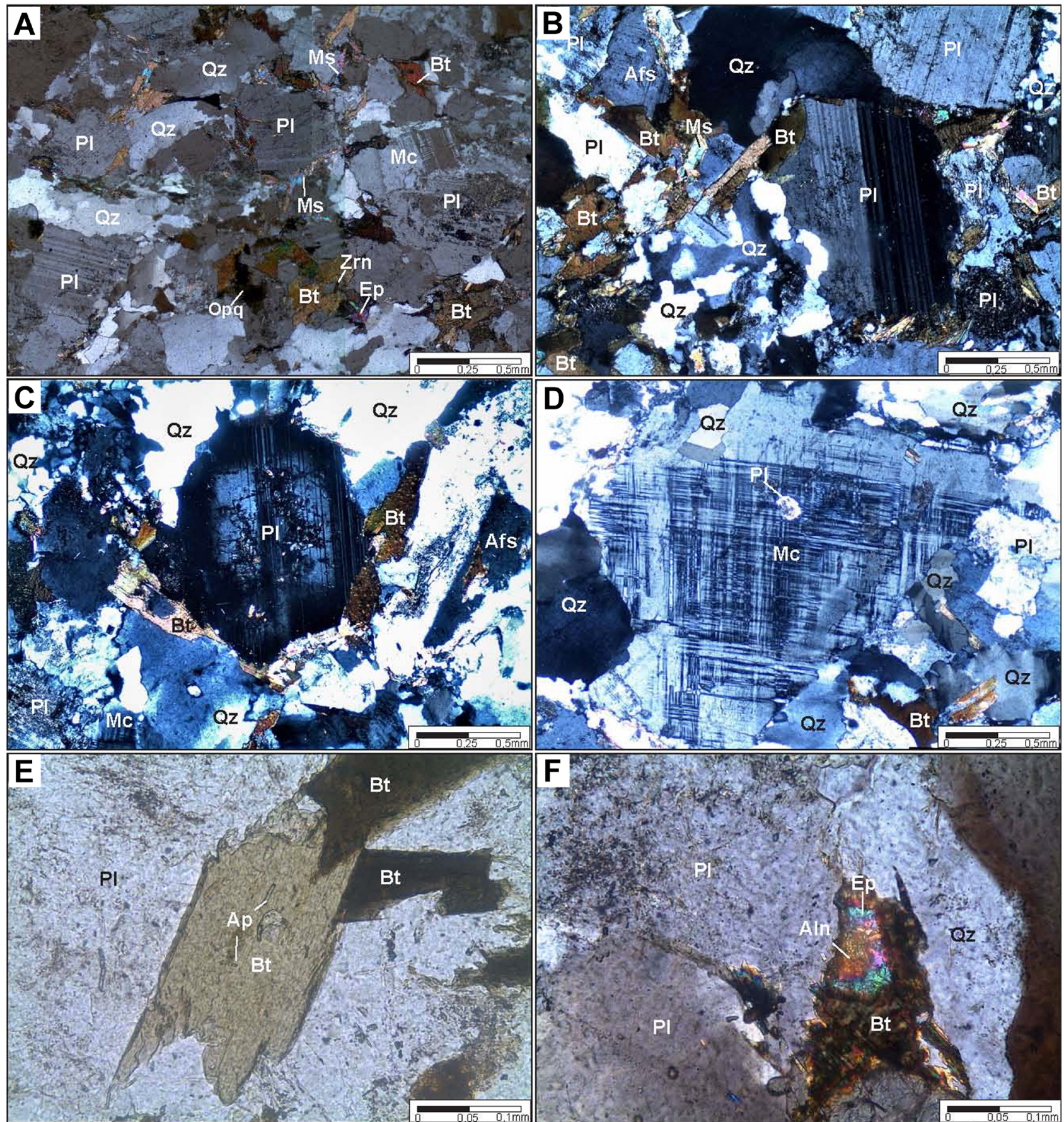

Qz: quartzo; PI: plagioclásio; Mc: microclima; Afs: feldspato alcalino; Bt: biotita; Ep: epídoto; Aln: allanita; Ms: muscovita; Opq: minerais opacos; Zrn: zircão; Ap: apatita.

Figura 6. Fotomicrografias de texturas das rochas do Stock Serra da Vaca. (A) Textura hipidiomórfica característica das rochas do Stock Serra da Vaca. (B) Cristal subédrico de plagioclásio exibindo geminação albita-Carlsbad. (C) Cristal subédrico de plagioclásio com geminação albita-Carlsbad e com extinção ondulante concêntrica, refletindo a zonação composicional. (D) Cristal de microclina anédrica, poiquilítica, incluindo plagioclásio, e com geminação em padrão albitapericlina. (E) Textura frequente dos cristais subédricos de biotita. $(F)$ Cristal de epídoto subédrico com núcleo de allanita, parcialmente incluso em cristais de biotita. Imagens A, B, C, D, F foram obtidas a nicóis cruzados. Imagem E foi obtida a nicóis paralelos. 
Tabela 2. Análises representativas por EDS-MEV de cristais de feldspato com fórmula estrutural calculada com base em 8 oxigênios. Moléculas de ortoclásio (Or), albita (Ab), anortita (An) e celsiana (Cn).

\begin{tabular}{|c|c|c|c|c|c|c|c|c|c|c|c|c|c|c|c|c|c|c|c|c|c|c|c|c|c|c|c|c|}
\hline & \multicolumn{4}{|c|}{234} & \multicolumn{2}{|c|}{235} & \multicolumn{4}{|c|}{803} & \multicolumn{2}{|c|}{804} & \multicolumn{4}{|c|}{806} & \multicolumn{2}{|c|}{1005} & \multicolumn{4}{|c|}{1013} & \multicolumn{2}{|c|}{1022} & \multicolumn{4}{|c|}{1024} \\
\hline $\mathrm{SiO}_{2}$ & 61,0 & 61,5 & 63,9 & 57,8 & 60,8 & 63,6 & 65,3 & 66,9 & 66,0 & 60,7 & 61,3 & 66,4 & 55,5 & 58,5 & 61,1 & 59,3 & 60,6 & 63,2 & 60,9 & 62,4 & 64,1 & 63,7 & 64,9 & 64,0 & 63,3 & 64,6 & 63,7 & 63,3 \\
\hline $\mathrm{Al}_{2} \mathrm{O}_{3}$ & 25,1 & 24,6 & 23,0 & 27,6 & 24,9 & 19,1 & 22,1 & 20,6 & 18,9 & 25,0 & 24,9 & 21,3 & 28,6 & 26,5 & 24,8 & 25,9 & 24,9 & 19,7 & 25,0 & 23,8 & 19,0 & 23,0 & 22,4 & 18,7 & 23,4 & 22,5 & 19,0 & 23,4 \\
\hline $\mathrm{CaO}$ & 5,5 & 5,2 & 3,0 & 6,9 & 5,2 & & 1,9 & 0,5 & & 5,3 & 4,8 & 1,3 & 9,7 & 7,9 & 5,4 & 7,0 & 6,1 & & 5,8 & 4,6 & & 3,7 & 0,6 & & 3,9 & 2,8 & & 3,9 \\
\hline $\mathrm{Na}_{2} \mathrm{O}$ & 8,4 & 8,6 & 10,0 & 7,8 & 9,1 & 0,4 & 10,8 & 11,8 & 0,6 & 8,7 & 9,0 & 11,0 & 6,2 & 7,0 & 8,4 & 7,5 & 8,0 & 0,7 & 8,3 & 9,0 & 0,8 & 9,6 & 10,8 & 0,4 & 9,3 & 10,0 & 0,5 & 9,3 \\
\hline $\mathrm{K}_{2} \mathrm{O}$ & & & & & & 15,6 & & & 14,6 & 0,3 & & & & 0,2 & 0,2 & 0,4 & 0,4 & 14,8 & & & 15,7 & & 1,3 & 16,3 & & 0,2 & 16,1 & \\
\hline $\mathrm{BaO}$ & & & & & & 1,2 & & & & & & & & & & & & 1,6 & & & 0,4 & & & 0,6 & & & 0,7 & \\
\hline Total & 100,0 & 99,9 & 99,9 & 100,1 & 100,0 & 99,9 & 100,1 & 99,8 & 100,1 & 100,0 & 100,0 & 100,0 & 100,0 & 100,1 & 99,9 & 100,1 & 100,0 & 100,0 & 100,0 & 99,8 & 100,0 & 100,0 & 100,0 & 100,0 & 99,9 & 100,1 & 100,0 & 99,9 \\
\hline $\mathrm{Si}$ & 2,705 & 2,727 & 2,818 & 2,578 & 2,702 & 2,962 & 2,867 & 2,937 & 3,012 & 2,699 & 2,717 & 2,910 & 2,495 & 2,611 & 2,714 & 2,644 & 2,697 & 2,940 & 2,703 & 2,765 & 2,969 & 2,810 & 2,863 & 2,975 & 2,795 & 2,843 & 2,962 & 2,795 \\
\hline $\mathrm{Al}$ & 1,312 & 1,286 & 1,196 & 1,451 & 1,304 & 1,048 & 1,144 & 1,066 & 1,017 & 1,310 & 1,301 & 1,100 & 1,515 & 1,394 & 1,298 & 1,361 & 1,306 & 1,080 & 1,308 & 1,243 & 1,037 & 1,196 & 1,165 & 1,025 & 1,218 & 1,167 & 1,042 & 1,218 \\
\hline $\mathrm{Ca}$ & 0,261 & 0,247 & 0,142 & 0,330 & 0,248 & & 0,089 & 0,024 & & 0,253 & 0,228 & 0,061 & 0,467 & 0,378 & 0,257 & 0,334 & 0,291 & & 0,276 & 0,218 & & 0,175 & 0,028 & & 0,185 & 0,132 & & 0,185 \\
\hline $\mathrm{Na}$ & 0,722 & 0,739 & 0,855 & 0,675 & 0,784 & 0,036 & 0,920 & 1,005 & 0,053 & 0,750 & 0,773 & 0,935 & 0,540 & 0,606 & 0,723 & 0,648 & 0,690 & 0,063 & 0,714 & 0,773 & 0,072 & 0,821 & 0,924 & 0,036 & 0,796 & 0,853 & 0,045 & 0,796 \\
\hline K & & & & & & 0,927 & & & 0,850 & 0,017 & & & & 0,011 & 0,011 & 0,023 & 0,023 & 0,878 & & & 0,927 & & 0,073 & 0,967 & & 0,011 & 0,955 & \\
\hline $\mathrm{Ba}$ & & & & & & 0,022 & & & & & & & & & & & & 0,029 & & & 0,007 & & & 0,011 & & & 0,013 & \\
\hline Total & 5,000 & 5,000 & 5,011 & 5,034 & 5,038 & 4,995 & 5,020 & 5,032 & 4,931 & 5,029 & 5,019 & 5,007 & 5,018 & 5,000 & 5,004 & 5,011 & 5,007 & 4,991 & 5,001 & 5,000 & 5,012 & 5,002 & 5,053 & 5,014 & 4,994 & 5,006 & 5,017 & 4,994 \\
\hline \multicolumn{29}{|c|}{$\mathbf{l}$} \\
\hline Or & & & & & & 94,1 & & & 94,1 & 1,7 & & & & 1,1 & 1,1 & 2,3 & 2,3 & 90,5 & & & 92,1 & & 7,1 & 95,4 & & 1,1 & 94,3 & \\
\hline$A b$ & 73,4 & 75,0 & 85,8 & 67,2 & 76,0 & 3,7 & 91,1 & 97,7 & 5,9 & 73,6 & 77,2 & 93,9 & 53,6 & 60,9 & 72,9 & 64,5 & 68,8 & 6,5 & 72,1 & 78,0 & 7,1 & 82,4 & 90,1 & 3,6 & 81,2 & 85,6 & 4,5 & 81,2 \\
\hline An & 26,6 & 25,0 & 14,2 & 32,8 & 24,0 & & 8,9 & 2,3 & & 24,8 & 22,8 & 6,1 & 46,4 & 38,0 & 25,9 & 33,3 & 29,0 & & 27,9 & 22,0 & & 17,6 & 2,8 & & 18,8 & 13,2 & & 18,8 \\
\hline $\mathrm{Cn}$ & & & & & & 2,2 & & & & & & & & & & & & 3,0 & & & 0,7 & & & 1,1 & & & 1,3 & \\
\hline
\end{tabular}
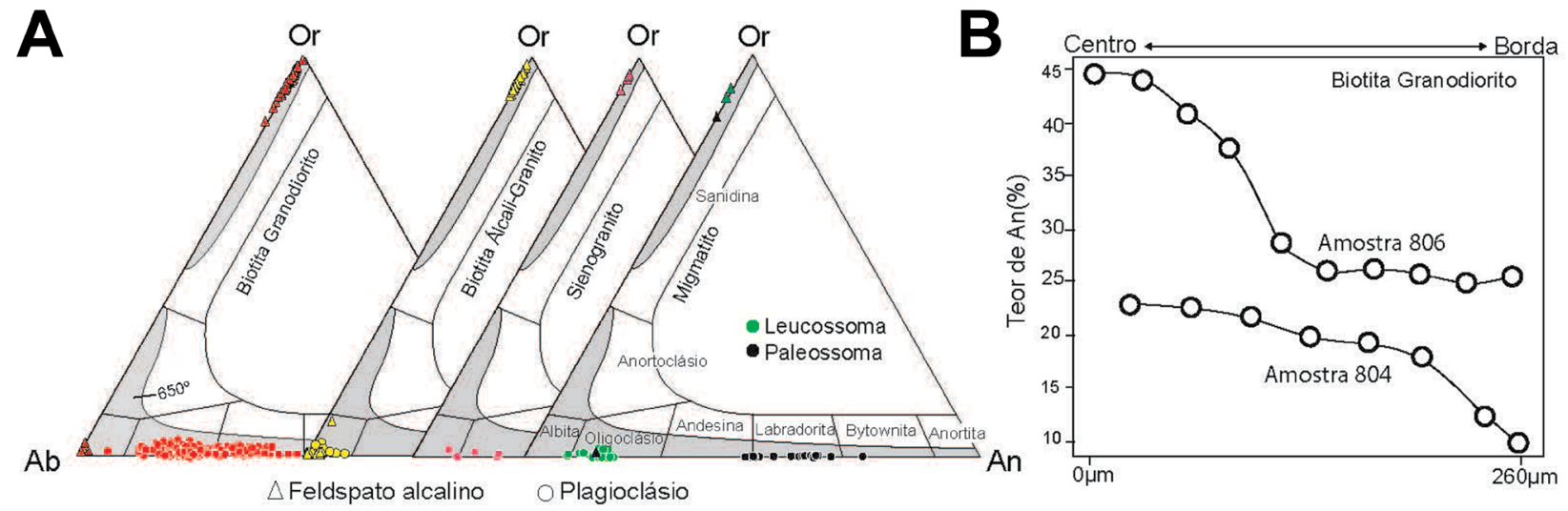

Figura 7. Diagramas químicos apresentado as composições dos cristais de plagioclásio e feldspato alcalino nas rochas estudadas. (A) Diagramas ternários Ortoclásio (Or) - Albita (Ab) - Anortita (An) com os resultados da composição dos feldspatos obtidos para os diferentes tipos de rochas do Stock Serra da Vaca e do Complexo Migmatítico Poço Redondo. A área cinza nos diagramas corresponde as composições de feldspatos na temperatura de $650^{\circ} \mathrm{C}$, segundo Fuhrman e Lindslay (1988). (B) Diagrama Teor de Anortita (\%An) versus a distância centro-borda em cristais de plagioclásio de granodioritos.

A biotita marrom é euédrica e subédrica (Figura 6E), com tamanhos que variam de $0,12-1,72 \mathrm{~mm}$, predominando cristais com $0,45 \mathrm{~mm}$. Exibe pleocroísmo em tons de marrom-escuro ( $\left.\sim \mathrm{z}^{\prime}\right)$, marrom-claro ( $\left.\sim \mathrm{y}^{\prime}\right)$ e amarelo $\left(\sim x^{\prime}\right)$. Os contatos são retos a irregulares com os demais minerais da rocha. Inclui, com frequência, apatita, zircão, epídoto zonado e com núcleo de allanita, bem como minerais opacos. Observa-se a presença de muscovita secundária $(<1,1 \mathrm{~mm})$, clorita e minerais opacos posicionados ao longo dos planos de clivagem e fraturas. A biotita tem razão $\mathrm{Fe} /(\mathrm{Fe}+\mathrm{Mg})$ variando entre 0,565 e 0,678 e valores de $\mathrm{Al}^{\mathrm{IV}}$ (Tabela 3) que variam de 2,348-2,558 átomos por fórmula unitária (apfu; Figura 8A). A maioria dos cristais de biotita apresenta composição magmática preservada, existindo igualmente cristais se alocam no campo da biotita primária reequilibrada (Figura $8 \mathrm{~B}$ ).

O epídoto ocorre em dois grupos distinguíveis por suas texturas distintas. O primeiro é formado por cristais euédricos e subédricos com tamanho médio de $0,2 \mathrm{~mm}$ e que têm, comumente, núcleo de allanita (Figura 6F). Esses cristais foram considerados magmáticos de cristalização precoce, anterior à dos feldspatos e biotita; adicionalmente, presentam também texturas de embainhamento. Cristais com estas feições são interpretados como 
Tabela 3. Análises químicas representativas obtidas com EDS-MEV de cristais de biotita do Stock Serra da Vaca. A fórmula estrutural foi calculada com base em 22 oxigênios.

\begin{tabular}{|c|c|c|c|c|c|c|c|c|c|c|c|c|c|c|c|c|c|c|c|c|c|c|c|}
\hline \multirow{2}{*}{$\frac{\text { Lâmina }}{\mathrm{SiO}_{2}}$} & \multicolumn{3}{|c|}{234} & \multicolumn{2}{|c|}{235} & \multicolumn{3}{|c|}{803} & \multicolumn{3}{|c|}{806} & \multicolumn{3}{|c|}{1005} & \multicolumn{3}{|c|}{1013} & \multicolumn{3}{|c|}{1022} & \multicolumn{3}{|c|}{809} \\
\hline & 36,7 & 36,9 & 36,3 & 35,8 & 34,9 & 34,5 & 36,2 & 38,8 & 36,4 & 37,2 & 35,9 & 36,7 & 35,7 & 36,1 & 36,2 & 36,3 & 34,9 & 34,8 & 35,5 & 35,8 & 38,4 & 37,9 & 39,0 \\
\hline $\mathrm{TiO}_{2}$ & 2,8 & 3,1 & 2,9 & 3,6 & 3,6 & 2,1 & 2,0 & 2,4 & 2,7 & 2,7 & 2,0 & 2,5 & 2,8 & 3,6 & 2,6 & 2,6 & 3,0 & 3,4 & 2,7 & 2,8 & 3,0 & 2,0 & 1,3 \\
\hline $\mathrm{Al}_{2} \mathrm{O}_{3}$ & 17,1 & 17,6 & 17,7 & 16,8 & 16,2 & 21,4 & 20,1 & 20,1 & 16,5 & 17,7 & 16,8 & 16,8 & 17,1 & 17,1 & 16,6 & 17,6 & 16,5 & 16,5 & 16,8 & 16,8 & 19,0 & 18,4 & 17,8 \\
\hline $\mathrm{FeO}$ & 21,8 & 21,2 & 20,9 & 23,3 & 24,5 & 26,8 & 27,3 & 22,2 & 22,7 & 20,7 & 24,0 & 22,8 & 22,9 & 22,1 & 22,8 & 21,8 & 23,6 & 24,4 & 22,9 & 22,8 & 16,8 & 19,0 & 18,8 \\
\hline $\mathrm{MnO}$ & 0,5 & 0,3 & 0,3 & & 0,3 & 0,4 & 0,4 & 0,3 & 0,3 & 0,2 & 0,3 & 0,1 & 0,3 & 0,3 & 0,5 & 0,4 & 0,5 & 0,5 & 0,5 & 0,5 & 0,4 & 0,3 & 0,4 \\
\hline $\mathrm{MgO}$ & 7,9 & 8,5 & 8,0 & 6,9 & 6,5 & 2,0 & 2,3 & 3,6 & 7,4 & 8,3 & 7,1 & 8,6 & 8,1 & 7,7 & 7,8 & 8,2 & 7,4 & 6,8 & 7,6 & 8,2 & 9,4 & 8,4 & 9,9 \\
\hline $\mathrm{K}_{2} \mathrm{O}$ & 9,4 & 8,5 & 9,5 & 9,5 & 9,9 & 8,9 & 7,7 & 8,6 & 9,7 & 8,9 & 9,8 & 8,4 & 9,2 & 9,2 & 9,5 & 8,5 & 9,2 & 9,8 & 9,7 & 9,1 & 8,9 & 9,3 & 8,4 \\
\hline $\mathrm{F}$ & 0,4 & & 0,7 & & & & & & 0,4 & 0,3 & & & & & 0,4 & 0,6 & 0,4 & 0,2 & 0,2 & 0,2 & 0,3 & 0,1 & 0,1 \\
\hline $\mathrm{Cl}$ & 0,1 & & 0,1 & & 0,1 & & & 0,1 & & 0,1 & & 0,1 & 0,1 & & 0,1 & 0,1 & 0,1 & 0,1 & & & & & \\
\hline Subtotal & 96,6 & 96,1 & 96,4 & 95,9 & 96,0 & 96,1 & 96,0 & 96,1 & 96,1 & 96,1 & 95,9 & 96,0 & 96,2 & 96,1 & 96,5 & 96,0 & 95,6 & 96,5 & 95,9 & 96,2 & 96,2 & 95,4 & 95,6 \\
\hline $\mathrm{O}=\mathrm{F}, \mathrm{Cl}$ & $-0,2$ & & $-0,3$ & & & & & 0,0 & $-0,2$ & $-0,1$ & & 0,0 & 0,0 & & $-0,2$ & $-0,3$ & $-0,2$ & $-0,1$ & $-0,1$ & 0,0 & $-0,1$ & $-0,1$ & $-0,1$ \\
\hline Total & 96,4 & 96,1 & 96,1 & 95,9 & 96,0 & 96,1 & 96,0 & 96,1 & 95,9 & 96,0 & 95,9 & 96,0 & 96,2 & 96,1 & 96,3 & 95,8 & 95,4 & 96,4 & 95,8 & 96,2 & 96,2 & 95,3 & 95,6 \\
\hline $\mathrm{Si}$ & 5,598 & 5,571 & 5,551 & 5,521 & 5,459 & 5,363 & 5,593 & 5,829 & 5,621 & 5,634 & 5,575 & 5,595 & 5,488 & 5,523 & 5,575 & 5,556 & 5,453 & 5,424 & 5,508 & 5,509 & 5,671 & 5,690 & 5,789 \\
\hline $\mathrm{Al}^{\mathrm{iv}}$ & 2,402 & 2,429 & 2,449 & 2,479 & 2,541 & 2,637 & 2,407 & 2,171 & 2,379 & 2,366 & 2,425 & 2,405 & 2,512 & 2,477 & 2,425 & 2,444 & 2,547 & 2,576 & 2,492 & 2,491 & 2,329 & 2,310 & 2,211 \\
\hline Alvi & 0,673 & 0,700 & 0,736 & 0,575 & 0,447 & 1,289 & 1,248 & 1,383 & 0,628 & 0,791 & 0,649 & 0,616 & 0,584 & 0,605 & 0,591 & 0,726 & 0,490 & 0,462 & 0,579 & 0,555 & 0,979 & 0,950 & 0,898 \\
\hline $\mathrm{Ti}$ & 0,320 & 0,349 & 0,331 & 0,423 & 0,429 & 0,247 & 0,234 & 0,271 & 0,312 & 0,307 & 0,235 & 0,286 & 0,322 & 0,409 & 0,300 & 0,298 & 0,349 & 0,394 & 0,313 & 0,322 & 0,331 & 0,228 & 0,150 \\
\hline $\mathrm{Fe}$ & 2,782 & 2,681 & 2,677 & 3,008 & 3,199 & 3,486 & 3,524 & 2,787 & 2,927 & 2,630 & 3,116 & 2,915 & 2,949 & 2,825 & 2,944 & 2,790 & 3,082 & 3,183 & 2,976 & 2,940 & 2,075 & 2,385 & 2,337 \\
\hline $\mathrm{Mn}$ & 0,062 & 0,037 & 0,037 & & 0,038 & 0,051 & 0,050 & 0,037 & 0,038 & 0,025 & 0,038 & 0,012 & 0,037 & 0,037 & 0,063 & 0,050 & 0,063 & 0,063 & 0,063 & 0,063 & 0,048 & 0,037 & 0,048 \\
\hline Mg & 1,791 & 1,925 & 1,817 & 1,589 & 1,520 & 0,468 & 0,531 & 0,817 & 1,702 & 1,866 & 1,644 & 1,965 & 1,847 & 1,752 & 1,786 & 1,862 & 1,720 & 1,586 & 1,753 & 1,871 & 2,071 & 1,868 & 2,189 \\
\hline K & 1,832 & 1,647 & 1,854 & 1,869 & 1,970 & 1,772 & 1,514 & 1,656 & 1,911 & 1,727 & 1,939 & 1,625 & 1,807 & 1,799 & 1,867 & 1,668 & 1,834 & 1,949 & 1,918 & 1,790 & 1,682 & 1,782 & 1,582 \\
\hline $\mathrm{OH}^{*}$ & 3,781 & 4,000 & 3,635 & 4,000 & 3,974 & 4,000 & 4,000 & 3,975 & 3,805 & 3,830 & 4,000 & 3,974 & 3,974 & 4,000 & 3,779 & 3,684 & 3,776 & 3,875 & 3,902 & 3,974 & 3,882 & 3,832 & 3,928 \\
\hline $\mathrm{F}$ & 0,193 & & 0,339 & & & & & & 0,195 & 0,144 & & & & & 0,195 & 0,291 & 0,197 & 0,099 & 0,098 & & 0,093 & 0,142 & 0,047 \\
\hline $\mathrm{Cl}$ & 0,026 & & 0,026 & & 0,026 & & & 0,025 & & 0,026 & & 0,026 & 0,026 & & 0,026 & 0,026 & 0,026 & 0,026 & & 0,026 & 0,025 & 0,025 & 0,025 \\
\hline Total & 19,461 & 19,339 & 19,453 & 19,464 & 19,603 & 19,313 & 19,102 & 18,951 & 19,518 & 19,345 & 19,622 & 19,421 & 19,546 & 19,427 & 19,550 & 19,395 & 19,538 & 19,638 & 19,602 & 19,541 & 19,185 & 19,343 & 19,297 \\
\hline
\end{tabular}
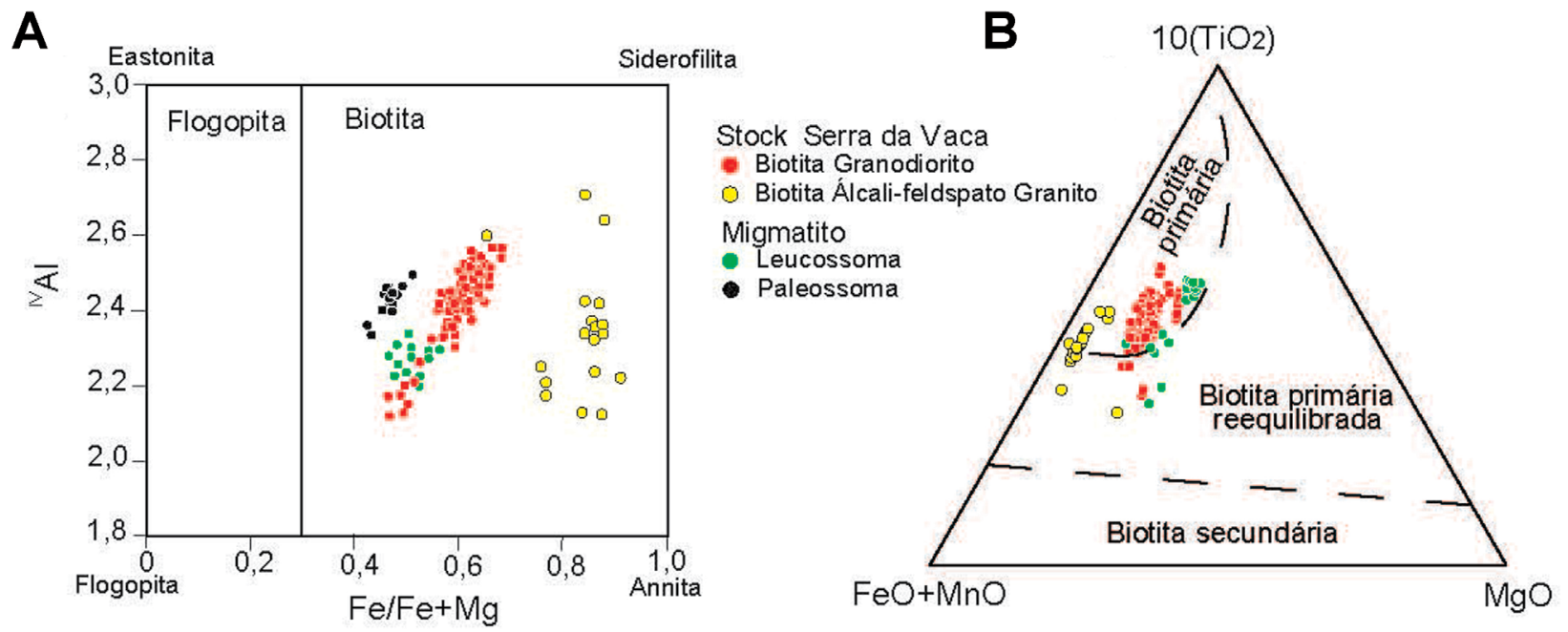

Figura 8. Diagramas utilizados para a classificação de cristais de biotita. (A) Diagrama Alv versus $\mathrm{Fe} /(\mathrm{Fe}+\mathrm{Mg})$ para nomear cristais de mica marrom, segundo Speer (1984). (B) Diagrama triangular $\left(10 . \mathrm{TiO}_{2}\right)-(\mathrm{FeO}+\mathrm{MnO})=\mathrm{MgO}$, proposto por Nachit et al. (2005), para discriminação entre cristais de biotita primário, primário reequilibrado e secundário.

magmáticos por Zen e Hammarstrom (1984) e Sial (1990). O segundo grupo, com granulometria $<0,08 \mathrm{~mm}$, é formado por cristais anédricos, subédricos e euédricos aciculares e está associado à saussutização do plagioclásio. As análises químicas dos cristais de epídoto apresentam conteúdo da molécula de pistacita $\left(\mathrm{Ps}=\left[\mathrm{Fe}^{3+} / \mathrm{Fe}^{3+}+\mathrm{Al}\right]^{*} 100\right)$ variando de 19,9-28,8\% (Tabela 4), sendo que os cristais do primeiro grupo apresentaram os maiores conteúdos de pistacita. Segundo alguns autores (e.g. Tulloch, 1979; Johnston e Wyllie, 1988; Sial, 1990; Sial e Ferreira, 2016), o percentual de pistacita (Ps) no epídoto pode indicar origem magmática ou hidrotermal. Quando os cristais de epídoto apresentam teores de Ps variando de 24-29\%, infere-se origem magmática. Por outro lado, quando os teores de 
Tabela 4. Análises químicas representativas de cristais de epídoto obtidas por EDS-MEV de rochas do Stock Serra da Vaca. $O$ cálculo da fórmula estrutural foi feito com base anidra em 25 oxigênios.

\begin{tabular}{|c|c|c|c|c|c|c|c|c|c|c|c|c|c|c|c|c|c|c|c|c|}
\hline \multirow{2}{*}{$\frac{\text { Lâmina }}{\mathrm{SiO}_{2}}$} & \multicolumn{3}{|c|}{234} & \multicolumn{3}{|c|}{235} & \multicolumn{3}{|c|}{804} & \multicolumn{3}{|c|}{806} & \multicolumn{3}{|c|}{1005} & \multirow{2}{*}{$\frac{1013}{39,6}$} & \multicolumn{4}{|c|}{1022} \\
\hline & 38,4 & 39,4 & 40,8 & 37,4 & 38,9 & 39,9 & 41,2 & 41,9 & 42,5 & 42,8 & 39,6 & 40,2 & 38,9 & 39,3 & 39,0 & & 39,5 & 39,6 & 40,5 & 41,6 \\
\hline $\mathrm{Al}_{2} \mathrm{O}_{3}$ & 26,6 & 25,9 & 24,8 & 23,4 & 24,9 & 26,0 & 25,2 & 26,6 & 26,1 & 25,6 & 25,0 & 26,7 & 23,8 & 24,9 & 24,8 & 24,7 & 25,4 & 24,0 & 24,9 & 24,5 \\
\hline $\mathrm{FeO}$ & 11,3 & 11,0 & 11,3 & 13,1 & 12,1 & 10,5 & 11,5 & 9,7 & 9,6 & 10,3 & 12,0 & 9,6 & 13,6 & 12,1 & 12,2 & 12,5 & 11,6 & 13,3 & 2,1 & 11,8 \\
\hline $\mathrm{CaO}$ & 23,7 & 23,8 & 23,1 & 26,0 & 24,1 & 23,6 & 22,2 & 21,8 & 21,7 & 21,3 & 23,4 & 23,5 & 23,6 & 23,4 & 23,6 & 23,2 & 23,5 & 23,2 & 22,5 & 21,2 \\
\hline Total & 100,0 & 100,1 & 100,0 & 99,9 & 100,0 & 100,0 & 100,1 & 100,0 & 99,9 & 100,0 & 100,0 & 100,0 & 99,90 & 99,70 & 99,60 & 100,00 & 100,00 & 100,10 & 100,00 & 99,10 \\
\hline $\mathrm{Si}$ & ,88 & 6,01 & 6,21 & 5,83 & 5,97 & 6,07 & 6,24 & 6,30 & 6,38 & 6,42 & 6,05 & 6,10 & 6,00 & 6,03 & 6,00 & 6,06 & 6,04 & 6,07 & 6,16 & 6,31 \\
\hline Al & 4,80 & 4,67 & 4,45 & 4,30 & 4,51 & 4,67 & 4,50 & 4,71 & 4,62 & 4,53 & 4,51 & 4,77 & 4,32 & 4,51 & 4,50 & 4,45 & 4,57 & 4,33 & 4,47 & 4,38 \\
\hline $\mathrm{Ca}$ & 3,89 & 3,89 & 3,76 & 4,34 & 3,97 & 3,85 & 3,60 & 3,51 & 3,49 & 3,43 & 3,83 & 3,82 & 90 & 3,85 & 3,89 & 3,80 & 3,85 & 3,81 & 3,67 & 3,45 \\
\hline $\mathrm{H}$ & 1,00 & 1,00 & 1,00 & 1,00 & 1,00 & 1,00 & 1,00 & 1,00 & 1,00 & 1,00 & 1,00 & 1,00 & 1,00 & 1,00 & 1,00 & 1,00 & 1,00 & 1,000 & 1,000 & 1,000 \\
\hline Total & 17,00 & 16,96 & 16,85 & 17,17 & 17,00 & 16,93 & 16,79 & 16,74 & 16,70 & 16,67 & 16,93 & 16,91 & 16,97 & 16,94 & 16,96 & 16,91 & 16,94 & 16,91 & 16,84 & 16,63 \\
\hline \%Ps & 23,2 & 23,2 & 24,4 & 28,4 & 25,6 & 22,3 & 24,5 & 20,6 & 20,7 & 22,2 & 25,4 & 20,3 & 28,8 & 25,6 & 25,9 & 26,4 & 24,5 & 28,2 & 25,6 & 25,5 \\
\hline
\end{tabular}

Ps são menores do que $24 \%$ e no intervalo de $36-48 \%$, atribui-se origem hidrotermal. Desse modo, com base nos dados obtidos, os cristais de epídoto do SSV são magmáticos com alguns indivíduos hidrotermais.

Os minerais acessórios dessas rochas são: allanita $(<0,2 \mathrm{~mm})$ subédrica, zonada e metamitizada; ilmenita; magnetita; titanita; zircão e apatita. O EDS possibilitou, ainda, identificar a presença dos seguintes minerais acessórios: torita, bastnäsita, calcita, fluorita e monazita. A torita, bastnäsita e calcita ocorrem associados à allanita, sendo provavelmente produto de sua alteração. A fluorita e a monazita são inclusões frequentes em biotita.

\section{Biotita álcali-feldspato granito}

A amostra 803 tem composição de biotita álcali-feldspato granito e ocorre na região nordeste do SSV. Essa rocha tem cor acinzentada, textura inequigranular e granulação fina a média, e a foliação magmática orienta cristais de biotita.

O plagioclásio é albita $\left(\mathrm{An}_{2-4}\right.$, Figura $\left.7 \mathrm{~A}\right)$, diferindo das outras rochas que compõem o SSV. Esses cristais apresentam formas subédrica e anédrica, bem como exibem geminação albita. Os tamanhos variam de 0,2-2 mm, predominando os de $0,8 \mathrm{~mm}$. Os contatos são irregulares com os demais cristais da rocha. Por vezes, quando em contato com o feldspato potássico, nota-se a presença da textura mirmequítica. Incluem quartzo anédrico $(<0,2 \mathrm{~mm})$, epídoto anédrico $(<0,2 \mathrm{~mm})$, biotita subédrica $(>0,5 \mathrm{~mm})$ e apatita euédrica $(<0,05 \mathrm{~mm})$.

A microclina pertítica é subédrica e anédrica, bem como apresenta geminação albita-periclina com resquícios da Carlsbad. A granulação varia de $0,8-2 \mathrm{~mm}$, predominando indivíduos com 1,2 mm. Os contatos são irregulares com os demais cristais da rocha. Observam-se inclusões de quartzo anédrico $(<0,15 \mathrm{~mm})$, epídoto anédrico $(<0,2 \mathrm{~mm})$, biotita subédrica $(<0,4 \mathrm{~mm})$, apatita subédrica $(<0,05 \mathrm{~mm}) \mathrm{e}$ albita $(<0,4 \mathrm{~mm})$. As composições das fases exsolvidas na microclina são: potássica $\mathrm{Or}_{91,3} \mathrm{Ab}_{8,7} \mathrm{An}_{0,0}$ até $\mathrm{Or}_{97,1} \mathrm{Ab}_{2,9} \mathrm{An}_{0,0}$ e sódica $\mathrm{Ab}_{98} \mathrm{Or}_{2} \mathrm{An}_{0}$ até $\mathrm{Ab}_{100} \mathrm{Or}_{0} \mathrm{An}_{0}$ (Figura 7).

Os cristais de quartzo são anédricos, com tamanhos variando de $0,2-1,66 \mathrm{~mm}$, e predominam os cristais com 0,5 $\mathrm{mm}$. É frequente a presença de extinção ondulante em barra. Os contatos são ameboides com outros cristais da rocha.

A biotita marrom $(<2 \mathrm{~mm})$ subédrica exibe pleocroísmo marrom avermelhado a marrom amarelado. Os contatos são irregulares com albita, microclina e quartzo. Inclui zircão, minerais opacos e quartzo. As análises químicas desses cristais apresentam razões $\mathrm{Fe} /(\mathrm{Fe}+\mathrm{Mg})$ variando de $0,77-0,91$ (Figura 8A) e são superiores às de outros cristais de biotita do SSV. No diagrama de Nachit et al. (2005), esses cristais posicionam-se no campo da biotita primária (Figura $8 \mathrm{~B}$ ).

\section{Sienogranitos}

Os sienogranitos (amostras 1023 e 1024) localizam-se na região sul do SSV (Figura 3). Apresentam estrutura maciça, coloração rósea, textura equigranular e granulação fina a média.

A microclina pertítica é subédrica e anédrica, bem como apresenta geminação albita-periclina. Os tamanhos dos cristais variam de $0,3-2,0 \mathrm{~mm}$, com o predomínio daqueles com $0,9 \mathrm{~mm}$. Inclui frequentemente plagioclásio, quartzo e biotita. As composições das fases exsolvidas são: potássica $\left(\mathrm{Or}_{91,7-95,4} \mathrm{Ab}_{8,3-4,6} \mathrm{An}_{0-0}\right)$ e a sódica $\left(\mathrm{Ab}_{100} \mathrm{Or}_{0} \mathrm{An}_{0}\right.$; Figura $\left.7 \mathrm{~A}\right)$.

O plagioclásio nessas rochas é zonado e corresponde a albita $\left(\mathrm{An}_{7-10}\right)$ e oligoclásio ( $\mathrm{An}_{13-19} ;$ Figura 7$)$. Os tamanhos variam de $0,2-2 \mathrm{~mm}$, predominando cristais com $0,8 \mathrm{~mm}$. Apresenta também geminação albita e inclusões de quartzo, epídoto zonado e com núcleo de allanita, bem como biotita.

Os cristais de biotita $(<0,4 \mathrm{~mm})$ apresentam-se alterados para clorita e muscovita. Têm-se, associados, cristais anédricos de ilmenita e magnetita anédricas. O quartzo (0,1-1,9 mm) é anédrico e apresenta extinção ondulante por setor. O epídoto tem cor verde-clara e exibe forma anédrica. 
Os tamanhos variam de $0,04-0,1 \mathrm{~mm}$, com o predomínio dos cristais com $0,08 \mathrm{~mm}$. Os cristais de zircão e apatita são euédricos e seus tamanhos não ultrapassam $0,12 \mathrm{~mm}$. Os cristais de magnetita e ilmenita $(0,08-0,6 \mathrm{~mm})$ são anédricos e ocorrem intimamente associados à desestabilização da mica marrom.

\section{Migmatito}

O leucossoma do migmatito apresenta composições de monzogranito (amostras 809 e 1006) a granodiorito (amostra 237) (Figura 5). Essas rochas têm granulação fina a média, com texturas inequigranular, porfiroblástica de matriz granoblástica. O plagioclásio é subdioblástico e corresponde ao oligoclásio $\left(\mathrm{An}_{15,4-20}\right.$; Figura $\left.7 \mathrm{~A}\right)$. A microclina $\left(\mathrm{Or}_{84,2}\right.$ $\left.\mathrm{Ab}_{15,8}-\mathrm{Or}_{90,8} \mathrm{Ab}_{9,2}\right)$ é subdioblástica e tem tamanhos menores do que 2,0 mm. A biotita marrom (Figura $8 \mathrm{~A}$ ) apresenta razões $\mathrm{Fe} /(\mathrm{Fe}+\mathrm{Mg})$ variando de $0,469-0,538$ e valores de Al total de 3,1-3,5 apfu. Apresenta composições que se alocam no campo dos cristais primários na Figura 8B. Os minerais acessórios são: epídoto, zircão, apatita, rutilo e ilmenita e magnetita.

O paleossoma do migmatito estudado (amostra 1011C) corresponde a granodiorito leucocrático. Essa rocha tem granulação média, textura granoblástica e inequigranular. Os cristais de plagioclásio são subdioblásticos $(0,3-6 \mathrm{~mm})$, apresentam geminação albita e têm composições de andesina $\left(\mathrm{An}_{48-50}\right)$, labradorita $\left(\mathrm{An}_{51-67}\right)$ e bytownita $\left(\mathrm{An}_{74} ;\right.$ Figura 7$)$. Ocasionalmente, alguns cristais exibem kink-bands e em outros observam-se bordas recristalizadas. A microclina $\left(\mathrm{Or}_{84-90} \mathrm{Ab}_{16-10}\right)$ é subdioblástica e geminada albita-periclina, por vezes as bordas apresentam-se recristalizadas. O quartzo é xenoblástico, tem tamanho entres intervalos de $0,1-2,1 \mathrm{~mm}$ e exibe extinção ondulante. A biotita marrom $(0,1-2,8 \mathrm{~mm})$, subdioblástica, ocorre orientada pela foliação metamórfica. Exibe razão $\mathrm{Fe} /(\mathrm{Fe}+\mathrm{Mg})$ variando de 0,42-0,51 e o conteúdo de $\mathrm{Al}_{\text {total }}$ variando de 2,8-3,1 apfu (Figura 8A). A mineralogia acessória do paleossoma é constituída por epídoto $(<0,4 \mathrm{~mm})$, allanita $(<0,34 \mathrm{~mm})$, titanita $(<0,9 \mathrm{~mm})$, ilmenita $(0,35 \mathrm{~mm})$, pirita $(0,1 \mathrm{~mm})$, zircão $(<0,07 \mathrm{~mm})$ e apatita $(0,03 \mathrm{~mm})$.

\section{GEOQUÍMICA}

Foram realizadas 13 análises químicas em rocha total em amostras representativas do SSV (10 amostras) e do migmatito (3 amostras). Os dados químicos obtidos estão apresentados na Tabela 5 .

As rochas do SSV são evoluídas, com os conteúdos (em peso) de $\mathrm{SiO}_{2}$ variando de 70,3-77,4\%. Os biotita granodioritos são as rochas que apresentam os menores valores de sílica $\left(70<\% \mathrm{SiO}_{2}<74\right)$, já o biotita álcali-granito e os sienogranitos exibem os valores mais elevados $\left(75<\% \mathrm{SiO}_{2}\right.$ $<77,5 \%$ ). As razões $\mathrm{K}_{2} \mathrm{O} / \mathrm{Na}_{2} \mathrm{O}$ dessas rochas variam de $0,81-4,35$, sendo que as amostras SOS-803 (biotita álcali-granito), 1023 e 1024 (sienogranitos) são as que exibem as maiores razões $\left(2,63<\mathrm{K}_{2} \mathrm{O} / \mathrm{Na}_{2} \mathrm{O}<4,35\right)$.

No diagrama total de álcalis versus $\mathrm{SiO}_{2}$ (Figura 9A), com os campos de Middlemost (1985), as rochas do SSV alocam-se no campo dos granitos. As rochas menos evoluídas do SSV exibem aumento do total de álcalis com o aumento do $\mathrm{SiO}_{2}$, sugerindo que a cristalização do feldspato alcalino é tardia. As amostras do migmatito posicionam-se nos campos do granodiorito (paleossoma) e do granito (leucossoma).

As rochas do SSV são peraluminosas $(1<\mathrm{A} / \mathrm{CNK}<1,1)$. Os migmatitos apresentam-se metaluminosos (paleossoma) e peraluminosos (leucossoma). Essas rochas (SSV e migmatitos) alocam-se no domínio dos granitos do tipo-I de Chappell e White (1992), indicando fonte e protólito ígneos (Figura 9B).

A afinidade geoquímica das rochas estudadas é investigada de acordo com a correlação entre $\mathrm{SiO}_{2}$ e $\mathrm{K}_{2} \mathrm{O}$ proposta por Peccerillo e Taylor (1976). No diagrama apresentado na Figura 9C as rochas menos diferenciadas (granodioritos) se posicionam no campo delimitado para as suítes cálcio-alcalina de alto $\mathrm{K}_{2} \mathrm{O}$. As outras rochas (biotita álcali-granito e sienogranitos) posicionam-se no campo das suítes shoshoníticas. Observa-se ainda, nesse mesmo diagrama, que essas rochas do SSV exibem correlação positiva do $\mathrm{K}_{2} \mathrm{O}$ com o aumento do $\mathrm{SiO}_{2}$, reforçando a hipótese de que a cristalização do feldspato alcalino é tardia.

Alguns autores, como, por exemplo Sylvester (1989), chamam a atenção para o fato de os granitos diferenciados $\left(\mathrm{SiO}_{2}>68 \%\right)$ convergirem para mesma posição ao serem alocados em digramas geoquímicos elaborados com os elementos maiores, existindo dificuldade em identificar a série magmática a que pertencem. Nesse sentido, Sylvester (1989) propõe o diagrama com razões entre elementos maiores para separar os tipos de granitos fracionados: cálcio-alcalinos altamente fracionados, cálcio-alcalino fortemente peraluminoso e alcalino (Figura 9D). As amostras dos granodioritos do SSV nesse diagrama alocam-se no campo cálcio-alcalino fortemente peraluminoso, já os sienogranitos (1024 e 1023), que correspondem às rochas mais evoluídas, posicionam-se no campo cálcio-alcalino fortemente diferenciado. A amostra 803 posiciona-se no campo alcalino.

A maioria das amostras do SSV se posiciona, no diagrama de Frost et al. (2001), no campo magnesiano, o que é coerente com ambiência orogênica do SOS. As rochas mais evoluídas $(803,1023$ e 1024) do SSV mostram assinaturas "ferroanas" (Figura 10A). No diagrama MALI (Frost et al., 2001), os granitos estudados abrangem dois campos: o cálcio-alcalino e o álcali-cálcico (Figura 10B).

Os espectros dos elementos terras raras (ETR) dos granodioritos e do álcali-feldspato granito apresentam-se com 
Tabela 5. Análises químicas de elementos maiores e traços das rochas do Stock Serra da Vaca, do Complexo Migmatítico de Poço Redondo e alguns parâmetros geoquímicos. LOI: perda ao fogo. Parâmetros geoquímicos: somatório dos elementos terras raras $(\Sigma E T R)$; razão entre $\mathrm{La}_{N}$ e Yb $\mathrm{b}_{N}\left((\mathrm{La} / \mathrm{Yb})_{N}\right) ;$ e $\left(\mathrm{Eu}^{\mathrm{E}} / \mathrm{Eu}^{*}\right)=\mathrm{Eu}_{N} / \sqrt{ }\left(\mathrm{Sm}_{N} \mathrm{Gd}_{N}\right)$.

\begin{tabular}{|c|c|c|c|c|c|c|c|c|c|c|c|c|c|}
\hline \multicolumn{11}{|c|}{ Stock Serra da Vaca } & \multicolumn{3}{|c|}{ Migmatitos } \\
\hline Amostra & 806 & 1005 & 804 & 234 & 235 & 1022 & 1013 & 803 & 1024 & 1023 & 1011C & 237 & 1006 \\
\hline $\begin{array}{l}\text { Nome da } \\
\text { rocha }\end{array}$ & Bt Grd & Bt Grd & Bt Grd & Bt Grd & Bt Grd & Bt Grd & Bt Grd & Bt Al Gr & Sgr & Sgr & Bt Grd & Bt Grd & Bt Mzn \\
\hline \multicolumn{14}{|l|}{$\%$ peso } \\
\hline $\mathrm{SiO}_{2}$ & 70,30 & 71,00 & 71,30 & 71,43 & 71,73 & 72,60 & 73,20 & 75,10 & 75,30 & 77,40 & 68,3 & 70,10 & 76,83 \\
\hline $\mathrm{TiO}_{2}^{2}$ & 0,38 & 0,35 & 0,33 & 0,37 & 0,31 & 0,19 & 0,31 & 0,18 & 0,09 & 0,05 & 0,4 & 0,25 & 0,12 \\
\hline $\mathrm{Al}_{2} \mathrm{O}_{3}$ & 15,20 & 15,75 & 14,85 & 14,67 & 14,52 & 14,00 & 15,05 & 10,70 & 12,30 & 11,75 & 15,5 & 14,96 & 12,31 \\
\hline $\mathrm{Fe}_{2} \mathrm{O}_{3}$ & 2,56 & 2,66 & 2,33 & 2,70 & 2,69 & 1,57 & 1,98 & 1,91 & 1,21 & 0,95 & 3,35 & 2,69 & 1,44 \\
\hline $\mathrm{MnO}^{\circ}$ & 0,04 & 0,04 & 0,05 & 0,06 & 0,04 & 0,03 & 0,05 & 0,03 & 0,02 & 0,01 & 0,06 & 0,04 & 0,02 \\
\hline $\mathrm{MgO}$ & 0,65 & 0,71 & 0,58 & 0,65 & 0,55 & 0,36 & 0,53 & 0,08 & 0,10 & 0,04 & 1,78 & 0,56 & 0,04 \\
\hline $\mathrm{CaO}$ & 2,68 & 3,15 & 2,37 & 2,28 & 1,99 & 1,72 & 2,05 & 0,11 & 0,50 & 0,30 & 3,29 & 2,46 & 0,42 \\
\hline $\mathrm{Na}_{2} \mathrm{O}$ & 3,83 & 3,67 & 3,73 & 3,66 & 3,47 & 3,44 & 4,12 & 1,53 & 2,34 & 2,11 & 3,73 & 3,31 & 2,71 \\
\hline $\mathrm{K}_{2} \mathrm{O}$ & 3,09 & 3,02 & 3,54 & 3,21 & 3,92 & 4,57 & 3,64 & 6,65 & 6,16 & 6,32 & 2,28 & 5,45 & 6,11 \\
\hline $\mathrm{P}_{2}^{2} \mathrm{O}_{5}$ & 0,14 & 0,13 & 0,11 & 0,12 & 0,10 & 0,08 & 0,12 & 0,01 & 0,02 & $<0.01$ & 0,13 & 0,12 & 0,01 \\
\hline LỐ & 0,56 & 0,61 & 0,43 & 0,60 & 0,40 & 0,74 & 0,64 & 0,41 & 0,46 & 0,56 & 0,51 & 0,5 & 0,24 \\
\hline Total & 99,43 & 101,09 & 99,62 & 99,75 & 99,72 & 99,30 & 101,69 & 96,71 & 98,50 & 99,49 & 99,56 & 100,44 & 100,24 \\
\hline \multicolumn{14}{|l|}{ ppm } \\
\hline $\mathrm{Cr}$ & $<10,0$ & 10,0 & $<10$ & 10,0 & 10,0 & $<10,0$ & 10,0 & $<10,0$ & $<10,0$ & $<10,0$ & & & \\
\hline V & 31,0 & 36,0 & 30,0 & 18,0 & 11,0 & 18,0 & 35 & 8,0 & 7,0 & 8,0 & & & \\
\hline Sn & 2,0 & 1,0 & 2,0 & 2,0 & 2,0 & 1,0 & 2,0 & 1,0 & $<1,0$ & $<1,0$ & & & \\
\hline $\mathrm{Ba}$ & 1.085 & 1.475 & 936 & 1.033 & 1.471 & 956 & 886 & 281 & 1.600 & 1.285 & & & \\
\hline $\mathrm{Rb}$ & 101 & 75,8 & 108,5 & 114,60 & 110,8 & 133,50 & 111 & 149,50 & 164 & 151 & & & \\
\hline Sr & 441 & 538 & 347 & 374,60 & 440,2 & 292 & 334 & 73,40 & 127 & 183 & & & \\
\hline $\mathrm{Ga}$ & 22,6 & 20,9 & 22,80 & 20,10 & 18,20 & 19,70 & 25,40 & 24,0 & 16,70 & 15,10 & & & \\
\hline $\mathrm{Zr}$ & 258 & 297 & 238 & 265,90 & 197,40 & 123,0 & 199 & 716 & 163 & 149 & & & \\
\hline Y & 9,2 & 8,60 & 16,50 & 11,90 & 8,50 & 14,40 & 15,40 & 23,10 & 71,00 & 11,20 & & & \\
\hline Cs & 2,65 & 1,47 & 4,49 & 5,0 & 2,60 & 1,42 & 1,42 & 1,95 & 3,64 & 1,56 & & & \\
\hline $\mathrm{Nb}$ & 11,8 & 6,20 & 14,10 & 17,80 & 9,30 & 12,10 & 22,70 & 17,30 & 5,70 & 3,10 & & & \\
\hline U & 0,57 & 0,76 & 1,36 & 1,50 & 0,80 & 1,73 & 0,49 & 0,92 & 2,44 & 2,29 & & & \\
\hline $\mathrm{La}$ & 41,60 & 53,70 & 52,80 & 43,0 & 52,10 & 30,20 & 36,80 & 100,50 & 28,90 & 4,20 & & & \\
\hline $\mathrm{Ce}$ & 86,90 & 112,50 & 120 & 88,40 & 104,10 & 62,70 & 84,50 & 234 & 100,50 & 22,70 & & & \\
\hline $\operatorname{Pr}$ & 30 & 11,80 & 12,45 & 9,77 & 11,02 & 7,14 & 9,18 & 25,10 & 8,40 & 1,40 & & & \\
\hline $\mathrm{Nd}$ & 34,30 & 41,70 & 45,10 & 34,70 & 39,50 & 26,30 & 33,30 & 90,80 & 33,70 & 5,60 & & & \\
\hline $\mathrm{Sm}$ & 5,82 & 6,55 & 7,84 & 5,59 & 6,63 & 5,00 & 5,77 & 18,55 & 8,92 & 2,57 & & & \\
\hline Eu & 1,34 & 1,53 & 1,23 & 1,12 & 1,39 & 0,86 & 1,19 & 0,82 & 0,94 & 0,63 & & & \\
\hline $\mathrm{Gd}$ & 3,36 & 3,81 & 4,35 & 3,54 & 4,27 & 4,37 & 4,17 & 14,10 & 10,20 & 2,16 & & & \\
\hline $\mathrm{Tb}$ & 0,42 & 0,46 & 0,64 & 0,47 & 0,46 & 0,57 & 0,56 & 1,79 & 1,73 & 0,43 & & & \\
\hline Dy & 2,41 & 2,22 & 3,71 & 2,45 & 2,02 & 3,59 & 3,45 & 8,78 & 12,45 & 2,92 & & & \\
\hline Ho & 0,30 & 0,32 & 0,64 & 0,47 & 0,32 & 0,69 & 0,58 & 1,22 & 2,78 & 0,60 & & & \\
\hline Er & 0,86 & 0,89 & 1,89 & 1,16 & 0,61 & 1,86 & 1,52 & 2,66 & 7,64 & 2,03 & & & \\
\hline $\mathrm{Tm}$ & 0,14 & 0,13 & 0,28 & 0,18 & 0,08 & 0,30 & 0,21 & 0,29 & 1,10 & 0,31 & & & \\
\hline $\mathrm{Yb}$ & 0,64 & 0,84 & 1,65 & 1,29 & 0,50 & 1,74 & 1,13 & 1,70 & 6,93 & 1,94 & & & \\
\hline Lu & 0,10 & 0,15 & 0,24 & 0,22 & 0,08 & 0,30 & 0,14 & 0,27 & 1,09 & 0,41 & & & \\
\hline Ta & 0,60 & 0,30 & 1,20 & 0,70 & 0,70 & 0,70 & 0,90 & 0,70 & 0,60 & 0,50 & & & \\
\hline $\mathrm{Hf}$ & 7,20 & 8,0 & 7,30 & 7,20 & 5,20 & 4,0 & 5,50 & 20,20 & 6,90 & 7,70 & & & \\
\hline Th & 13,0 & 10,90 & 13,90 & 10,60 & 17,60 & 10,0 & 10,60 & 14,05 & 13,05 & 10,45 & & & \\
\hline$\Sigma$ ETR & 187,49 & 236,6 & 252,82 & 192,36 & 223,08 & 145,62 & 182,5 & 500,58 & 225,28 & 47,9 & & & \\
\hline $\mathrm{K}_{2} \mathrm{O}+\mathrm{Na}_{2} \mathrm{O}$ & 6,92 & 6,69 & 7,27 & 6,87 & 7,39 & 8,01 & 7,76 & 8,18 & 8,50 & 8,43 & 6,11 & 8,76 & 8,82 \\
\hline $\mathrm{K} \mathrm{K}_{2} \mathrm{O} / \mathrm{Na}_{2} \mathrm{O}$ & 0,81 & 0,82 & 0,95 & 0,88 & 1,13 & 1,33 & 0,88 & 4,35 & 2,63 & 3,00 & 0,64 & 1,65 & 2,25 \\
\hline$(\mathrm{La} / \mathrm{Yb})_{\mathrm{N}}$ & 43,47 & 42,75 & 21,40 & 22,29 & 69,68 & 11,61 & 21,78 & 39,53 & 2,79 & 1,45 & & & \\
\hline $\mathrm{Eu} / \mathrm{Eu}^{*}$ & 0,93 & 0,94 & 0,65 & 0,77 & 0,80 & 0,57 & 0,75 & 0,16 & 0,30 & 0,82 & & & \\
\hline
\end{tabular}

Bt Grd: biotita granodiorito; Bt Mzn: biotita monzogranito; Sgr: sienogranito; Bt Al Gr: biotita álcali-granito. 

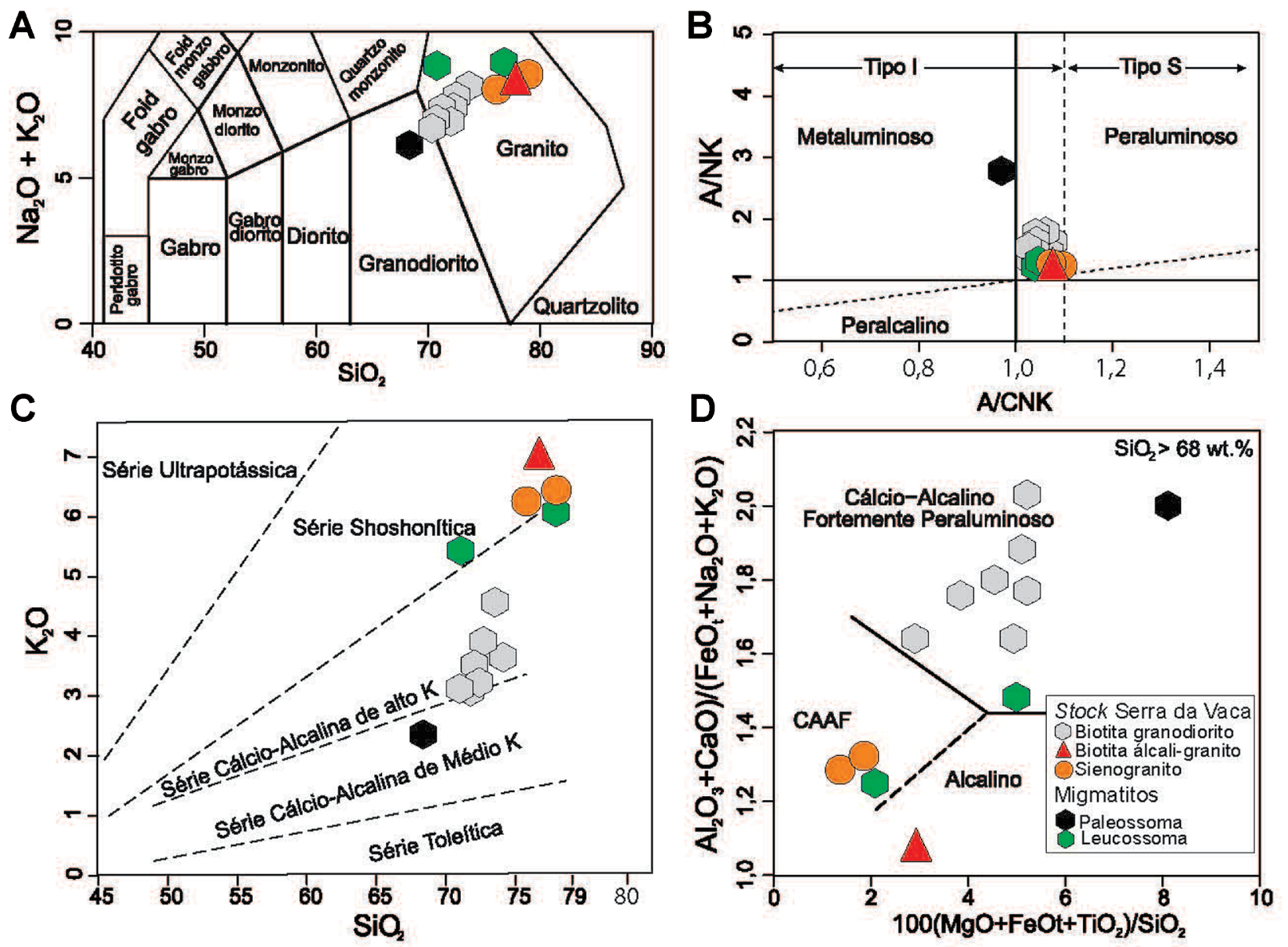

CAAF: cálcio-alcalino altamente fracionado.

Figura 9. Diagramas geoquímicos aplicados às rochas estudadas. (A) Diagrama $\mathrm{TAS}\left(\mathrm{Na}_{2} \mathrm{O}+\mathrm{K}_{2} \mathrm{O} \text { versus } \mathrm{SiO}\right)_{2}$ com campos definidos por Middlemost (1985). (B) Diagrama A/KN $\left[\mathrm{Al}_{2} \mathrm{O}_{3} /\left(\mathrm{K}_{2} \mathrm{O}+\mathrm{Na}_{2} \mathrm{O}\right)\right]$ versus A/CNK $\left[\mathrm{Al}_{2} \mathrm{O}_{3} /\left(\mathrm{CaO}+\mathrm{Na}_{2} \mathrm{O}+\right.\right.$ $\mathrm{K}_{2} \mathrm{O}$ )], de Maniar e Piccoli (1989), e com os campos dos granitos dos tipos I e S, segundo Chappell e White (1992). (C) Diagrama $\mathrm{K}_{2} \mathrm{O}$ versus $\mathrm{SiO}_{2}$, de Peccerillo e Taylor (1976), modificado por Corriveau e Gorton (1993). (D) Diagrama (Al $\mathrm{O}_{3}$ $\left.+\mathrm{CaO}) /\left(\mathrm{FeO}_{\mathrm{t}}+\mathrm{Na}_{2} \mathrm{O}+\mathrm{K}_{2} \mathrm{O}\right)\right]$ versus $\left[100\left(\mathrm{MgO}+\mathrm{FeOt}+\mathrm{TiO}_{2}\right) / \mathrm{SiO}_{2}\right]$, de Sylvester (1989), para classificação de granitos diferenciados $\left(\mathrm{SiO}_{2}>69 \%\right)$.

padrões inclinados e marcados pelo enriquecimento dos ETR leves em relação aos ETR pesados $\left(11<(\mathrm{La} / \mathrm{Yb})_{\mathrm{N}}<70\right.$; Figura 11). Os sienogranitos, que representam as rochas mais evoluídas $\left(\mathrm{SiO}_{2}>75 \%\right)$, exibem espectros distintos das outras rochas do SSV e se caracterizam por baixas razões $(\mathrm{La} / \mathrm{Yb})_{\mathrm{N}}$, com valores de 1,45 e 2,79 (Tabela 5). Os padrões da maioria das amostras são paralelos, sobretudo entre os granodioritos. Percebe-se que os padrões dos sienogranitos e do álcali-feldspato granito são bem distintos dos granodioritos, podendo indicar que essas rochas não são cogenéticas aos granodioritos ou sofreram processos de modificações posteriores. As anomalias de Eu são pouco pronunciadas para a maioria das amostras $\left(0,57<\mathrm{Eu} / \mathrm{Eu}^{*}<0,97\right)$, à exceção das amostras 803 (biotita álcali-granito) e 1024 (sienogranito), que exibem forte anomalia negativa: 0,16 e 0,30 , respectivamente.
Em diagramas multielementares (Figura 12), observa-se, em todas as amostras do SSV, o enriquecimento dos elementos LILE (K, Ba, Rb e Th) em comparação com os HFSE ( $\mathrm{Ta}, \mathrm{Nb}$ e Y). Essa característica é, segundo Fowler et al. (2008), feição típica de granitos cálcio-alcalinos (Figura 12). Ainda, é possível observar empobrecimentos relativos em $\mathrm{Nb}, \mathrm{Sr}, \mathrm{P} \mathrm{e} \mathrm{Ti}$, sendo esses mais marcados nos termos mais evoluídos (álcali-feldspato granito e sienogranitos).

\section{DISCUSSÃO}

A orientação NE-SW do SVV é paralela ao conjunto de falhas presentes na região norte do DPR. Santos et al. (1988) e Carvalho (2005) propuseram que os granitos no DPR 

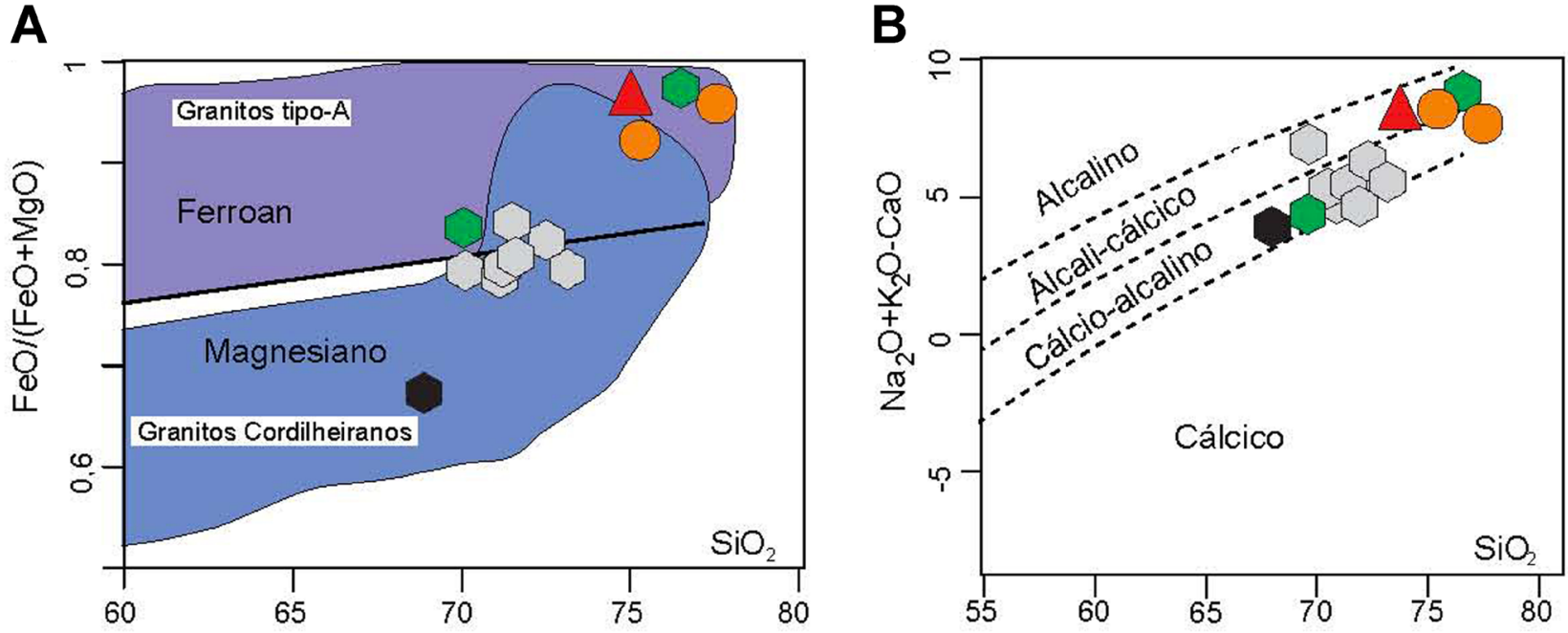

Figura 10. Diagramas geoquímicos de Frost et al. (2001). (A) Diagrama $\mathrm{SiO}_{2}$ versus $\mathrm{FeO} /(\mathrm{FeO}+\mathrm{MgO}) \mathrm{com}$ os campos de associações magnesiana (granidos cordilheiranos) e ferroan (granitos do tipo A). (B) Diagrama $\mathrm{SiO}_{2}$ versus Modified Alkali-lime Index $\left[\mathrm{MALI}=\mathrm{Na}_{2} \mathrm{O}+\mathrm{K}_{2} \mathrm{O}-\mathrm{CaO}\right]$ com os campos de rochas, segundo Frost et al. (2001). Mesmos símbolos da Figura 9.

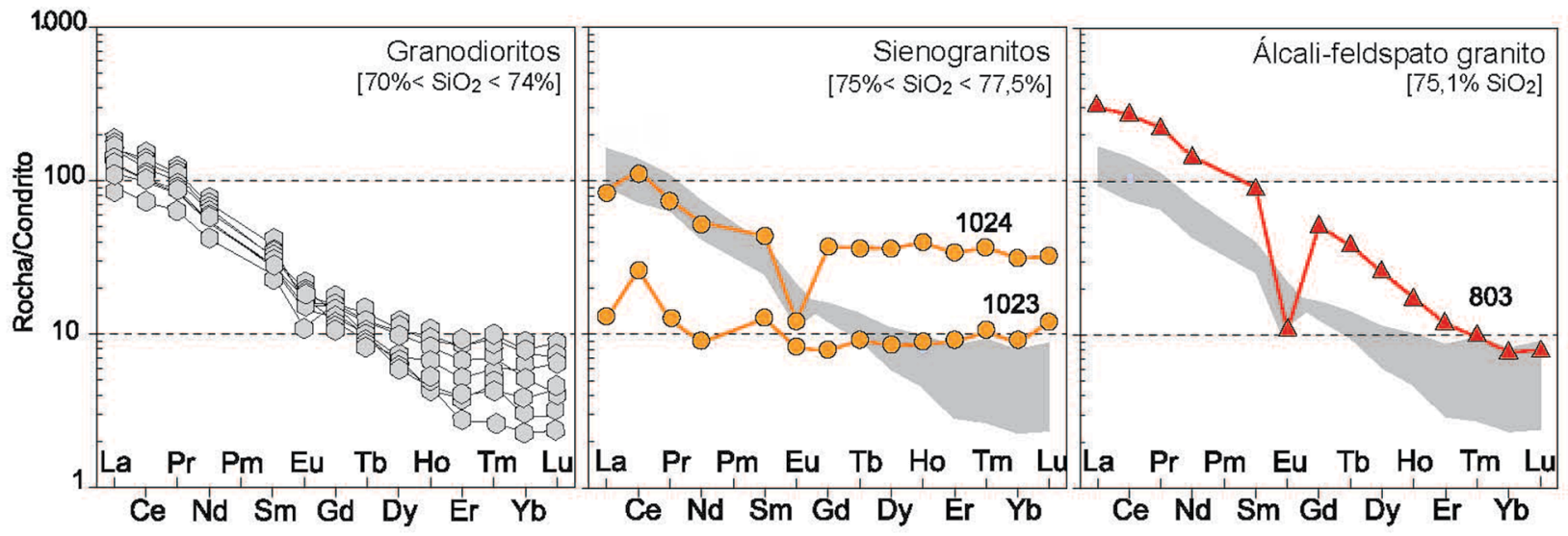

Figura 11. Diagramas com elementos terras raras, normalizados pelo condrito de Nakamura (1974), dos granitos do Stock Serra da Vaca. A área sombreada representa aquela ocupada pelos espectros dos biotita granodioritos para efeito de comparação.

com orientação NE-SW, como é o caso do SSV, refletem colocação condicionada às falhas em período pós-tectônico. A ausência da foliação regional (NW-SE) bem desenvolvida nos migmatitos nas rochas do SSV é a favor da hipótese de que a colocação desse stock seja posterior ao metamorfismo regional de médio grau.

Os dados modais das rochas estudadas do SSV evidenciam que esse stock é constituído essencialmente por granodioritos (região central), com ocorrências subordinadas sienogranitos (região sul) e álcali-feldspato granitos (região leste). Esses mesmos dados indicam afinidade cálcio-alcalina e origem dos granodioritos a partir de fusão parcial de protólito ígneo (Figura 13A). Os sienogranitos e álcali-feldspato granito alocam-se no campo das rochas de tipo-A, enquanto os granodioritos assemelham-se aos granitos de tipo-I. A composição química dos cristais de biotita dos granodioritos indicam afinidade cálcio-alcalina (Figura 13B) das rochas. Os cristais de biotita do álcali-granito posicionam-se nos campos cálcio-alcalino e peraluminoso.

Nos granodioritos do SSV, o plagioclásio apresenta zonação química normal (Figura 7B) e tem composições variando de andesina até oligoclásio (Figura 7A). Essas feições são 


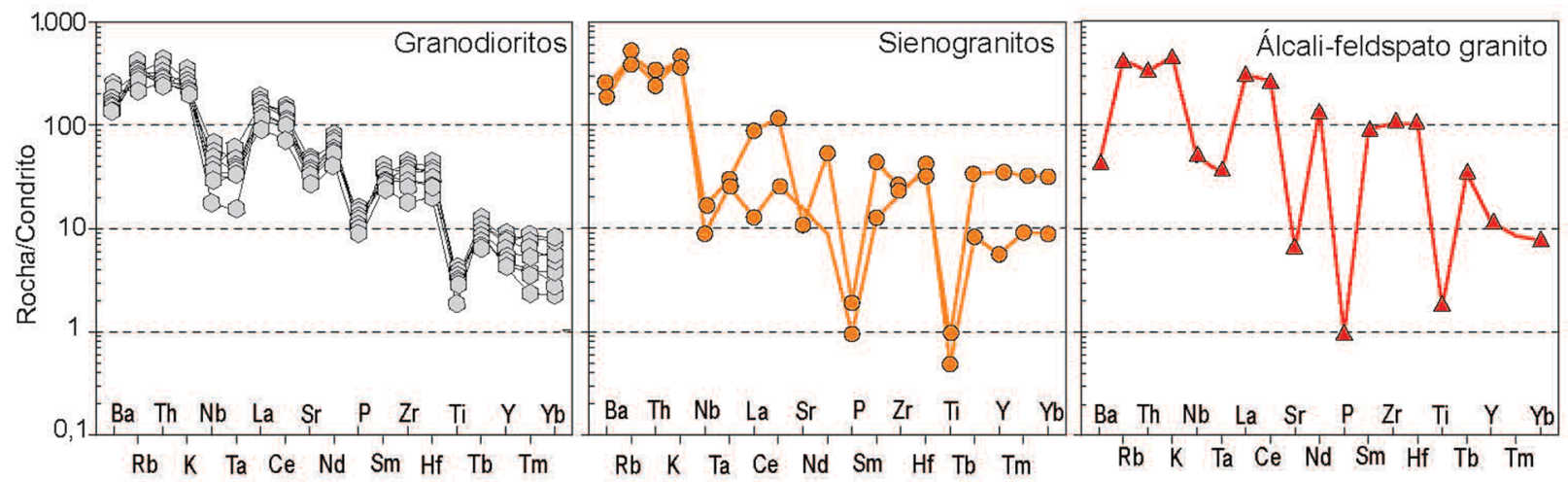

Figura 12. Diagramas multielementar de distribuição de elementos-traço para os granitos do Stock Serra da Vaca, normalizados pelos valores do condrito de Thompson (1982).
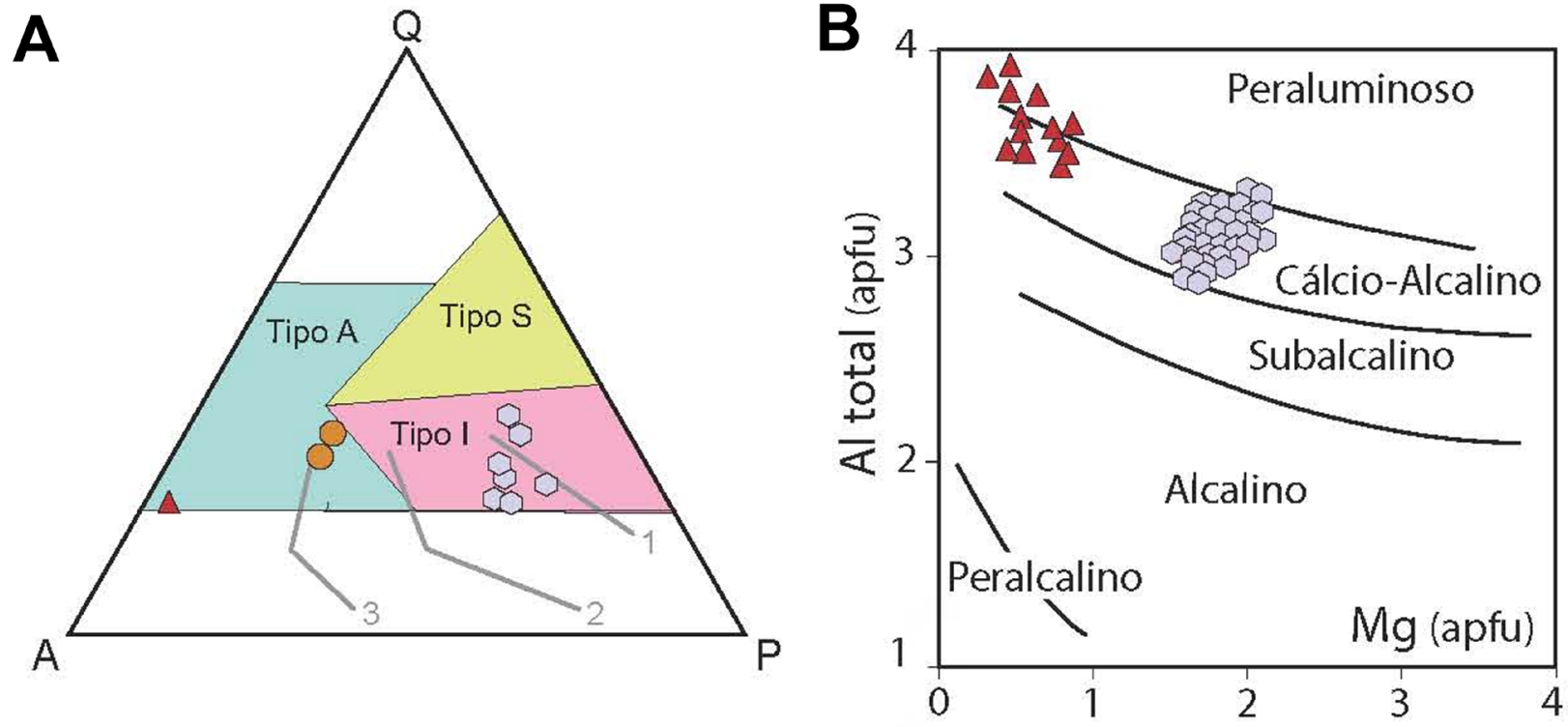

Figura 13. (A) Diagrama modal QAP com campos estabelecidos por Bowden et al. (1984) para granitos: anorogênicos (Tipo A) e formados por fusão de protólito metassedimentar (Tipo S) e ígneo (Tipo I). As retas no diagrama correspondem às evoluções das séries ígneas propostas por Lameyre e Bowden (1982): 1 - Cálcio-Alcalina de médio K (Tonalítica); 2 Cálcio-Alcalina de alto K (Granodiorítica); 3 - Shoshonítica (Monzonítica). (B) Diagrama Mg versus $\mathrm{Al}_{\text {total }}$, de Nachit et al. (1985), para inferência da afinidade peraluminosa, cálcio-acalina, subalcalina, alcalina e peralcalina, aplicado aos cristais de biotita das rochas do Stock Serra da Vaca. Mesmos símbolos da Figura 9.

indicativas, para vários autores (e.g. Loomis, 1982; Galindo et al., 2012), de evolução magmática controlada pelo processo de cristalização fracionada. Observou-se boa correlação negativa entre o $\mathrm{SiO}_{2}$ e outros óxidos (Figura 14) no SSV, o que sugere o fracionamento de plagioclásio $\left(\mathrm{CaO}, \mathrm{Na}_{2} \mathrm{O}\right.$, $\left.\mathrm{Al}_{2} \mathrm{O}_{3}\right)$, minerais opacos $\left(\mathrm{FeOt}, \mathrm{TiO}_{2}\right)$, epídoto $(\mathrm{CaO}, \mathrm{FeO}$, $\left.\mathrm{Al}_{2} \mathrm{O}_{3}\right)$, apatita $\left(\mathrm{CaO}, \mathrm{P}_{2} \mathrm{O}_{5}\right)$ e biotita $\left(\mathrm{TiO}_{2}, \mathrm{Al}_{2} \mathrm{O}_{3}, \mathrm{MgO}\right)$.
A presença de anomalias negativas em $\mathrm{Sr}$, Ti e $\mathrm{P}$, nos diagramas multielementares (Figura 12), reforça a hipótese de fracionamento de plagioclásio, biotita/minerais opacos e apatita, respectivamente. Já a correlação positiva do $\mathrm{K}_{2} \mathrm{O}$ com o $\mathrm{SiO}_{2}$ sugere cristalização tardia do feldspato alcalino. O posicionamento dos sienogranitos e álcali-feldspato granito deslocados da tendência evolucional nos diagramas do 

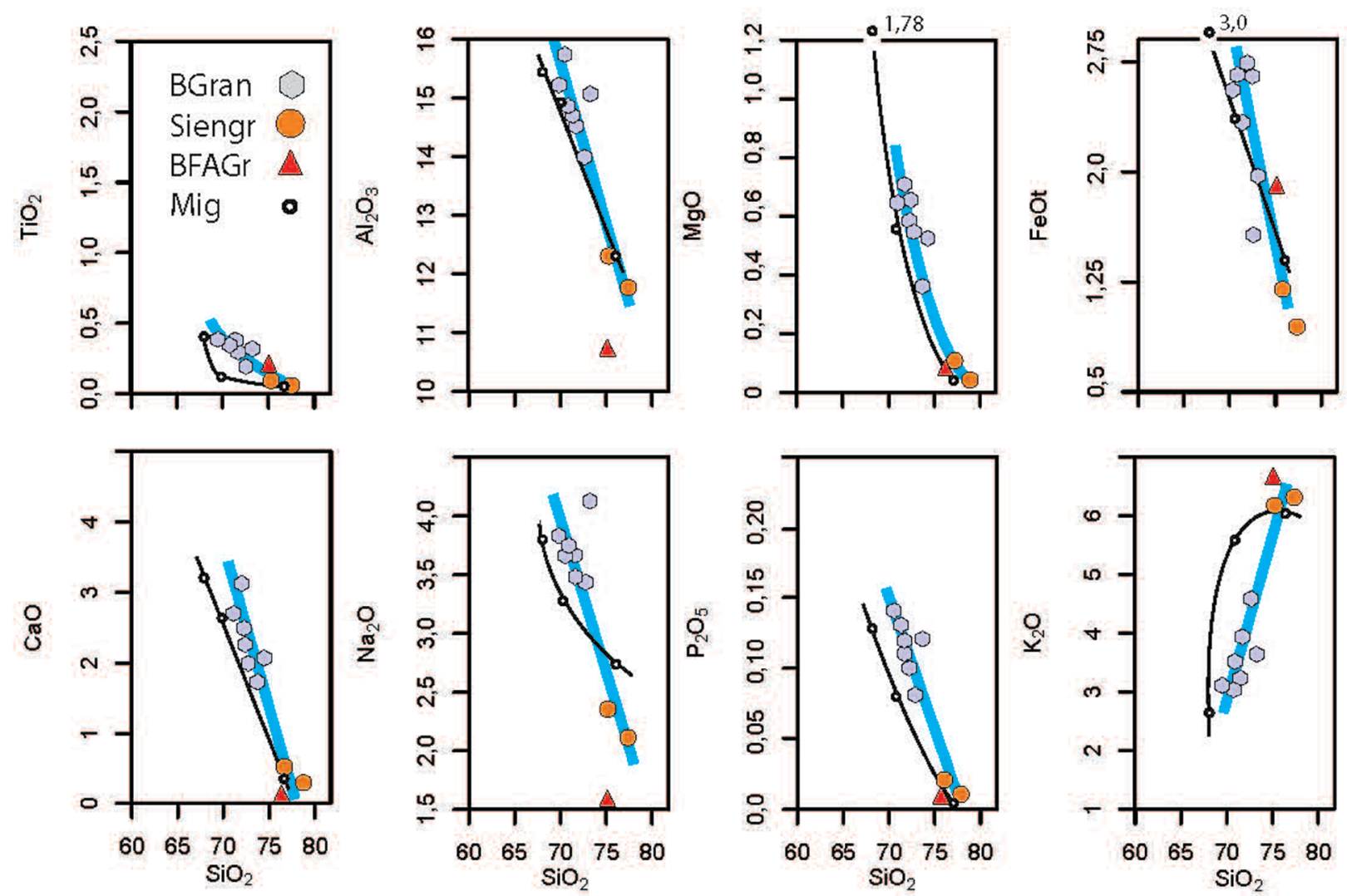

Figura 14. Diagramas de Harker aplicados aos granitos do Stock Serra da Vaca. Biotita granodiorito (BGran), sienogranito (Siengr), Biotita álcali-feldspato granito (BFAGr) e migmatito (Mig). A linha na cor azul indica a evolução das rochas do Stock Serra da Vaca, e a em preto, dos migmatitos.

tipo Harker pode indicar que essas rochas não representam produto da cristalização do magma granodiorítico.

Ao se comparar as evoluções químicas dos elementos maiores entre as rochas do SSV e os migmatitos (Figura 14), percebe-se que, com o aumento do $\mathrm{SiO}_{2}, \mathrm{TiO}_{2}, \mathrm{FeOt}, \mathrm{Na}_{2} \mathrm{O}$, $\mathrm{P}_{2} \mathrm{O}_{5}$ e $\mathrm{K}_{2} \mathrm{O}$ mostram comportamentos diferentes. As evoluções distintas entre os dois conjuntos de rochas sugerem que o magma do SSV não se originou dos migmatitos.

A presença de epídoto magmático nos granodioritos do SSV indica cristalização desse mineral a pressões da ordem de $6 \mathrm{kbar}$, conforme sugerido em trabalhos experimentais (e.g. Naney, 1983; Zen e Hammarstrom, 1984; Schmidt e Thompson, 1996). Essas pressões equivalem a cerca de 25 $\mathrm{km}$ de profundidade. Pressões próximas a essas são descritas em outras regiões da Província Borborema para alojamento de granitos cálcio-alcalinos com epídoto primário (Ferreira et al., 2011; Brasilino et al., 2011; Sial e Ferreira, 2016). Rochas similares com epídoto magmático foram identificadas nas suítes intrusivas Queimada Grande (Sousa et al., 2019) e Sítios Novos (Pinho Neto et al., 2019) no DPR. Segundo Brandon et al. (1996), para preservar cristais de epídoto formados a profundidades elevadas, é necessário que o magma ascenda relativamente rápido, para que o epídoto não seja reabsorvido pelo melt.

A associação allanita-epídoto, presente nos granodioritos do SSV, sugere cristalização em condições relativamente oxidantes para diversos autores (e.g. Frost, 1991; Schmidt e Thompson, 1996; Ferreira et al., 2011; Galindo et al., 2012). Condições oxidantes são igualmente responsáveis pela estabilidade da associação titanita-magnetita-quartzo (Wones, 1989) presente nas rochas estudadas. A ausência de pronunciadas anomalias negativas em Eu nos granodioritos pode refletir a presença dessas condições oxidantes. Pois, segundo Hanson (1980), alta fugacidade de oxigênio faz com que o $\mathrm{Eu}^{+2}$ oxide para $\mathrm{Eu}^{+3}$, e esse íon não tem tamanho para ser alojado na estrutura do plagioclásio, substituindo o cálcio. Por outro lado, a presença de importante anomalia negativa de Eu no álcali-granito (803) e no sienogranito (1023) pode indicar diminuição das condições de oxidação ou que essas rochas não tenham sido formadas pelo magma responsável pela formação dos granodioritos do SSV.

O caráter pós-tectônico do SSV inferido a partir de geologia e petrografia encontra suporte nos elementos-traço $\mathrm{Rb}$ 
(75-164 ppm), Y (8-71 ppm) e Nb (3-22 ppm, Figura 15). A relação entre esses mesmos elementos indica que o magmatismo SSV tem assinatura de ambiente de arco vulcânico. As relações entre os conteúdos de Th, Ta e Hf indicam que as rochas do SSV correspondem a produto de magmatismo

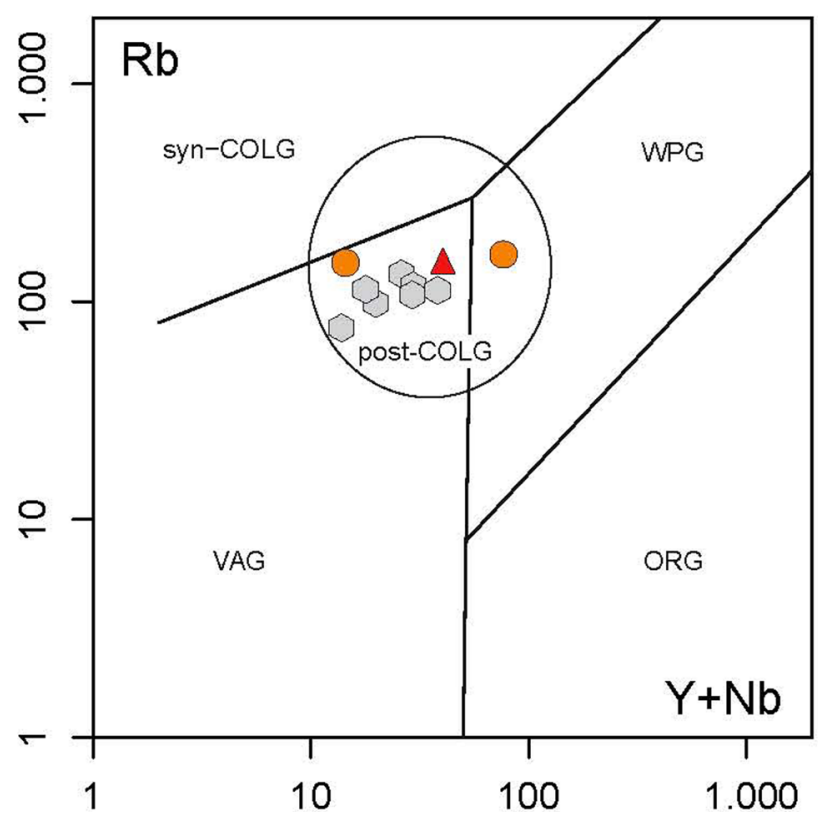

WPG: granitos intra-placa; ORG: granitos de cadeias oceânicas; syn-COLG: granitos sin-colisionais; VAG: granitos de arco-vulcânico; post-COLG: granitos pós-colisionais.

Figura 15. Diagrama $\mathrm{Rb}$ versus $\mathrm{Y}+\mathrm{Nb}$ de ambiência tectônica, após Pearce et al. (1984) e Pearce (1996). Mesmos símbolos da Figura 9. de margem continental ativa (Figura 16A). O enriquecimento em Th em relação ao Ta (Figura 16B) reflete, segundo Gorton e Schandl (2000), a assinatura de fluídos ricos em Th, característicos de magmas formados em zonas de subducção. Os vales de Ti, Ta e $\mathrm{Nb}$ presentes nos diagramas multielementares reforçam essa hipótese (Figura 12).

Os dados petrográficos, mineraloquímicos e geoquímicos sobre o SSV permitem avaliar a sua filiação com a Suíte Intrusiva Glória Xingó 2, como proposto por Teixeira et al. (2014). De acordo com Santos et al. (1998) e Teixeira et al. (2014), os granitos dessa suíte representam o plutonismo mais jovem do DPR, o qual ocorre essencialmente na forma de diques e pequenos stocks, constituídos por granitos róseos a cinza, granulação fina a média, maciços, classificados como leucogranitos (mais comuns), biotita granitos, muscovita granitos e turmalina-moscovita granitos. Ou seja, têm mineralogia característica de granitos formados a partir da fusão parcial de rochas metassedimentares: granitos tipo S (Chappell e White, 2001). A petrografia dos granodioritos do SSV corresponde a granitos cujo máfico é a biotita, sendo ausente mineralogia peraluminosa. Os dados obtidos sugerem que os granodioritos do SVV pertençam à Suíte Intrusiva Coronel João Sá definida por Teixeira et al. (2014): se caracteriza por reunir granodioritos, dioritos e granitos equigranulares de cor cinza, com poucos autólitos máficos, de natureza magnesiana, cálcio-alcalina de alto $\mathrm{K}$, metaluminosa a peraluminosa, com assinatura de tipo-I, como aparece na Figura 17.

As rochas do SSV correspondem a granodioritos cálcio-alcalinos, que, segundo Barbarin (1999), resultam de magmatismo com contribuições mantélica e crustal. A inferência
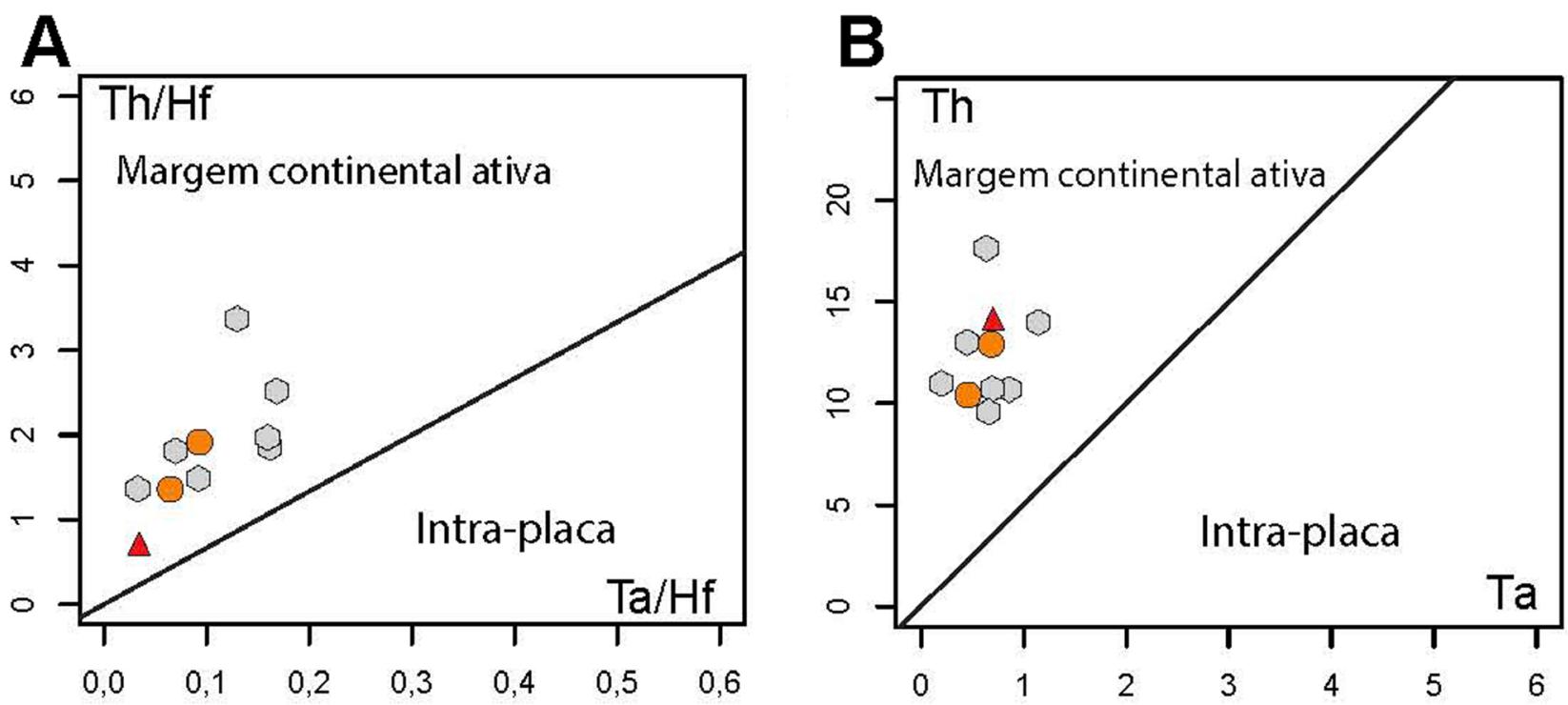

Figura 16. Diagramas de ambiência tectônica, após Gorton e Schandl (2000), aplicados aos granitos do SSV. (A) diagrama Th/Hf versus Ta/Hf. (B) diagrama Th versus Ta. Mesmos símbolos da Figura 9. 


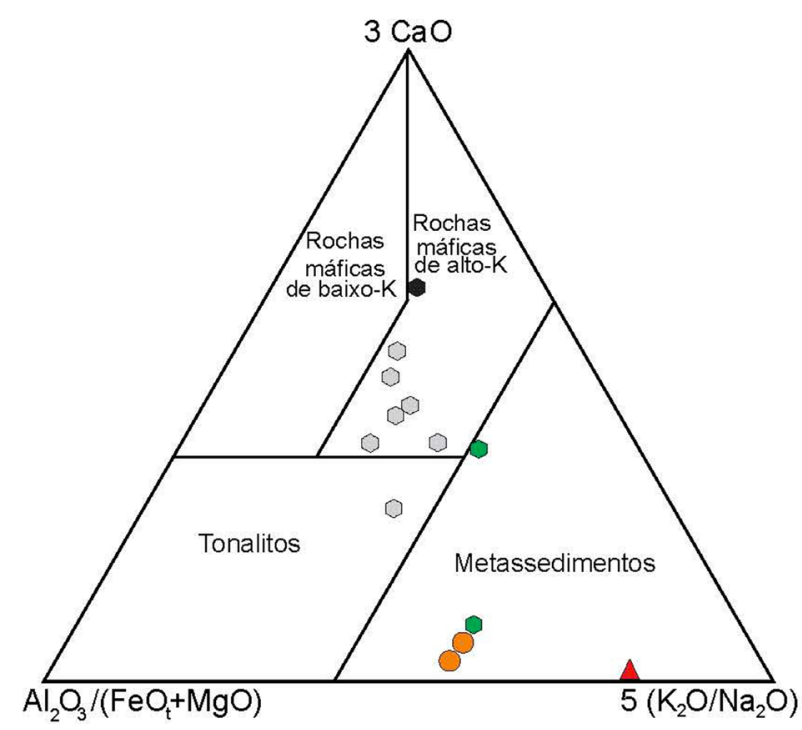

Figura 17. Diagrama ternário $\mathrm{Al}_{2} \mathrm{O}_{3} /(\mathrm{FeO}+\mathrm{MgO})$, $3 \mathrm{CaO}$, $5\left(\mathrm{~K}_{2} \mathrm{O} / \mathrm{Na}_{2} \mathrm{O}\right)$ com campos que representam composições de magmas derivados de variadas fontes, após Laurent et al. (2014). Mesmos símbolos da Figura 9.

sobre a provável fonte para as rochas do SSV é feita utilizando-se dados geoquímicos, e esses indicam que os granodioritos podem ter sido formados por rochas máficas de alto K (Figura 17). Nesse mesmo diagrama, as fontes para os sienogranitos e migmatito são indicadas como rochas metassedimentares.

\section{CONCLUSÕES}

O SVV, com $19 \mathrm{~km}^{2}$, é uma intrusão alongada na direção NE-SW, localizada na região NW do DPR, no SOS. Atribui-se, com base nos dados obtidos, que esse stock tem colocação controlada pelas falhas e posiciona-se em período pós-tectônico.

O estudo petrográfico identificou no SSV a presença dominante de biotita granodioritos (centro) e, de forma subordinada, de sienogranito (sul) e álcali-granito (leste). As texturas ígneas preservadas suportam cristalização pós-tectônica. A variação de composição do plagioclásio (andesina-oligoclásio) e a zonação normal sugerem que a evolução do magma granodiorítico se processou por cristalização fracionada. Os dados químicos suportam essa hipótese. Os sienogranitos e o álcali-feldspato granito aparentemente não correspondem a produtos fracionados dessa cristalização fracionada.

A presença de epídoto magmático e a paragênese titanita-magnetita-quartzo indicam início da cristalização a profundidades da ordem de $25 \mathrm{~km}$, sob condições relativamente oxidantes. As fracas anomalias em Eu nos granodioritos suportam essa hipótese.

Os dados obtidos para o SSV revelaram que esse stock não apresenta as características descritas para o magmatismo da Suíte Glória-Xingo 2, de gênese essencialmente crustal. Os dados obtidos sugerem que os granodioritos do SSV pertençam à Suíte Intrusiva Coronel João Sá, que é bem representada no Domínio Macururé. Nesse contexto, o magma cálcio-alcalino, responsável pela geração dos granodioritos do SSV, apresenta assinatura geoquímica de magmas oriundos de fontes máficas de alto $\mathrm{K}_{2} \mathrm{O}$, pós-colisional e intrusivos em arco vulcânico com assinatura de fluidos da subducção.

\section{AGRADECIMENTOS}

O presente trabalho foi realizado com apoio da Coordenação de Aperfeiçoamento de Pessoal de Nível Superior - Brasil (CAPES) - 001. O autor D.B. de Oliveira agradece à CAPES, por sua bolsa de mestrado. Os autores externam igualmente agradecimento ao Conselho Nacional de Desenvolvimento Científico e Tecnológico (CNPq), pelo suporte financeiro que permitiu a realização desta pesquisa (processos: 384713/2015-7, 405387/2016-4, 310391/2017-2, 311008/2017-8). Este trabalho é parte da dissertação de mestrado do primeiro autor que foi realizada no Laboratório de Petrologia Aplicada à Pesquisa Mineral (LAPA-UFS). Gostaríamos igualmente de agradecer as contribuições dos revisores da revista.

\section{REFERÊNCIAS}

Almeida, F. F. M., Brito Neves, B. B., Fuck, R. A. (1977). Províncias Estruturais Brasileiras. In: VIII Simpósio Geologia do Nordeste. Atas..., p. 363-391. Campina Grande: SBG.

Barbarin, B. (1999). A review of the relationships between granitoid types, their origins and their geodynamic environments. Lithos, 46(3), 605-626. https://doi.org/10.1016/ S0024-4937(98)00085-1

Bowden, P., Batchelor, R. A., Chappell, B. W., Didier, J., Lameyre, J. (1984). Petrological, geochemical and source criteria for the classification of granitic rocks: a discussion. Physics of the Earth and Planetary Interiors, 35(1-3), 1-11. https://doi.org/10.1016/0031-9201(84)90029-3

Brandon, A. D., Creaser, R. A., Chacko, T. (1996). Constraints on rates of granitic magma transport from epidote dissolution kinetics. Science, 271(5257), 1845-1848. https://doi. org/10.1126/Science.271.5257.1845 
Brasilino, R. G., Sial, A. N., Ferreira, V. P., Pimentel, M. M. (2011). Bulk rock and mineral chemistries and ascent rates of high-K calc-alkalic epidote-bearing magmas, Northeastern Brazil. Lithos, 127(3-4), 441-454. https://doi.org/10.1016/j. lithos.2011.09.017

Brito Neves, B. B., Sial, A. N., Albuquerque, J. P. T. (1977). Vergência centrífuga residual no sistema de dobramentos Sergipano. Revista Brasileira de Geociências, 7(2), 102-114.

Bueno, J. F., Oliveira, E. P., McNaughton, N., Laux, J. H. (2009). U-Pb dating of granites in the Neoproterozoic Sergipano Belt, NE-Brazil: Implications for the timing and duration of continental collision and extrusion tectonics in the Borborema Province. Gondwana Research, 15(1), 86-97. https://doi.org/10.1016/j.gr.2008.06.003

Carvalho, M. J. (2005). Evolução Tectônica do Domínio Marancó - Poço Redondo: Registro das Orogêneses Cariris Velhos e Brasiliana na Faixa Sergipana, NE do Brasil. Tese (Doutorado). Campinas: Universidade Estadual de Campinas.

Chappell, B. W., White, A. J. R. (1992). I- and S-type granites in the Lachlan Fold Belt. Transaction of Royal Society Edinburg: Earth Sciences, 83(1-2), 1-26. https:// doi.org/10.1017/S0263593300007720

Chappell, B. W., White, A. J. R. (2001). Two contrasting granite types: 25 years later. Australian Journal of Earth Sciences, 48(4), 489-499. https://doi.org/10.1046/j.1440-0952.2001.00882.x

Conceição, H., Rosa, M. L. S., Conceição, J. A., Lisboa, V. A. C., Pereira, F. S., Teles, D. S., Fernandes, D. M., Sousa, E. S., Cruz, J. W. S., Rezende, H. J. C., Oliveira, I. R., Souza, J. M. D. S., Oliveira, I. L. (2017). Magmatismos no Domínio Macururé, Sistema Orogênico Sergipano: estado de conhecimento. XXVII Simpósio de Geologia do Nordeste. João Pessoa: SBG.

Conceição, J. A., Rosa, M. L. S., Conceição, H. (2016). Sienogranitos leucocráticos do Domínio Macururé, Sistema Orogênico Sergipano, Nordeste do Brasil: Stock Glória Sul. Brazilian Journal of Geology, 46(1), 63-77. https://doi. org/10.1590/2317-4889201620150044

Corriveau, L., Gorton, M. P. (1993). Coexisting K-rich alkaline and shoshonitic magmatism arc affinities in the Proterozoic: a reassessment of syenitic stocks in the southwestern Grenville Province. Contribution to Mineralogy and Petrology, 113, 262-279. https://doi.org/10.1007/BF00283233

Davison, I., Santos, R. A. (1989). Tectonic evolution of the Sergipano fold belt, NE Brazil, during the Brasiliano orogeny. Precambrian Research, 45(4), 319-342. https:// doi.org/10.1016/0301-9268(89)90068-5

Deer, W. A., Howie, R. A., Zussman, J. (1992). An Introduction to the Rock-Forming Mineral. 2. ed. Harlow: Longman Scientific and Technical.

Ferreira, V. P., Sial, A. N., Pimentel, M. M., Armstrong, R., Spicuzza, M., Guimarães, I. P., Silva Filho, A. F. (2011). Contrasting sources and P-T crystallization conditions of epidote-bearing granitic rocks, northeastern Brazil: $\mathrm{O}, \mathrm{Sr}$, and Nd Isotopes. Lithos, 121(1-4), 189-201. https://doi. org/10.1016/j.lithos.2010.11.002

Fowler, M. B., Kocks, H., Darbyshire, D. P. F., Greenwood, P. B. (2008). Petrogenesis of high Ba-Sr plutons from the Northern Highlands Terrane of the British Caledonian Province. Lithos, 105(1-2), 129-148. https://doi.org/10.1016/j. lithos.2008.03.003

Frost, R. B. (1991). Introduction to oxigen fugacity and its petrologic importance. In: D. H. Lindsley (Ed.). Oxide minerals: petrologic and magnetic significance (v. 25, p. 1-10). Reviews in Mineralogy. Mineralogical Society of America.

Frost, B. R., Barnes, C. G., Collins, W. J., Arculus, R. J., Ellis, D. J., Frost, C. D. (2001). A geochemical classification of granitic rocks. Journal of Petrology, 42(11), 2033-2048. https://doi.org/10.1093/petrology/42.11.2033

Fuhrman, M. L., Lindsley, D. H. (1988). Ternary-feldspar modeling and thermometry. American Mineralogist, 73(34), 201-215.

Galindo, A. C., Silva, F. C. A., Souza, Z. S. (2012). Química mineral de leucomicrogranitos neoproterozoicos do Domínio Rio Grande do Norte. Geochimica Brasiliensis, 26(1), 19-28.

Gorton, M. P., Schandl, E. S. (2000). From Continents to Island Arc: A Geochemical Index of Tectonic Setting for Arc-Related and within Plate Felsic to Intermediate Volcanic Rocks. Canadian Mineralogist, 38(5), 1065-1073. https:// doi.org/10.2113/gscanmin.38.5.1065

Gouveia, S. G. (2016). Contribuição à petrografia e geoquímica do Stock Umbuzeiro do Matuto, Sistema Orogênico Sergipano. Trabalho de Conclusão de Curso. São Cristóvão: Universidade Federal de Sergipe - UFS.

Hanson, G. N. (1980). Rare earth elements in petrogenetic studies of igneous systems. Annual Review of Earth and Planetary Sciences, 8, 371-405. https://doi.org/10.1146/ annurev.ea.08.050180.002103 
Humphrey, L., Allard, G. O. (1967). O Geossinclinal de Propriá - província tectônica do pré-cambriano posterior, recém descoberta no escudo brasileiro. Boletim Técnico da Petrobras, 10(3-4), 409-430.

Johnston, A. D., Wyllie, P. J. (1988). Constraints on the origin of Archeant trondhjejemites based on phase relationships of Nuk gneiss with $\mathrm{H}_{2} \mathrm{O}$ at 15 kbar. Contributions to Mineralogy and Petrology, 100, 35-46. https://doi. org/10.1007/BF00399438

Lameyre, J., Bowden, P. (1982). Plutonic rocks types series: discrimination of various granitoide series and related rocks. Volcanology and Geothermal Research, 14(1-2), 169-186. https://doi.org/10.1016/0377-0273(82)90047-6

Laurent, O., Martin, H., Moyen, J. F., Doucelance, R. (2014). The diversity and evolution of late-Archean granitoids: Evidence for the onset of "modern-style" plate tectonics between 3.0 and $2.5 \mathrm{Ga}$. Lithos, 205, 208-235. https://doi. org/10.1016/j.lithos.2014.06.012

Le Maitre, R. W., Streckeisen, A., Zanettin, B., Le Bas, M. J., Bonin, B., Bateman, P., Bellieni, G., Dudek, A., Efremova, S., Keller, J., Lameyre, J., Sabine, P. A., Schimd, R., Sorensen, H., Woolley, A. R. (2002). Igneous Rocks - A classification and glossary of terms. Recommendations of the International Union of Geological Sciences-Subcommission on the Systematics of Igneous Rocks. 2. ed. Nova York: Cambridge University Press.

Lima, D. R. (2016). Caracterização petrológica e geoquímica do Plúton Curituba, Domínio Poço Redondo-Marancó, Cinturão Sergipano. Dissertação (Mestrado). Recife: Universidade Federal de Pernambuco.

Lima, M. M. C. (2013). Caracterização geoquímica, isotópica e geotectônica dos Complexos Araticum e Arapiraca, Faixa Sergipana, Alagoas, Nordeste do Brasil. Dissertação (Mestrado). Recife: Universidade Federal de Pernambuco.

Lisboa, V. A. C., Conceição, H., Rosa, M. L. S., Fernandes, D. M. (2019). The onset of post-collisional magmatism in the Macururé Domain, Sergipano Orogenic System: the Glória Norte Stock. Journal of South American Earth Sciences, 89, 173-188. https://doi.org/10.1016/j. jsames.2018.11.005

Long, L. E., Castellana, C. H., Sial, A. N. (2005). Age, origin and cooling history of the Coronel João Sá Pluton, Bahia, Brazil. Journal of Petrology, 46(2), 255-273. https://doi. org/10.1093/petrology/egh070
Loomis, T. P. (1982). Numerical simulations of cristallization processes of plagioclase in complex melts: the origin of major and Oscillatory zoning in plagioclase. Contributions to Mineralogy and Petrology, 81, 219-229. https://doi. org/10.1007/BF00371299

Maniar, P. D., Piccoli, P. M. (1989). Tectonic discrimination of granitoids. Geological Society American, 101(5), 635-643. https:// doi.org/10.1130/0016-7606(1989)101<0635:TDOG>2.3.CO;2

Mendes, V. A., Brito, M. F. L., Santos, C. A. (2011). Zona de cisalhamento contracional de Palmeira dos Índios. Um possível testemunho do evento Cariris Velhos na Província Borborema. In: XIII Simpósio Nacional de Estudos Tectônicos. Resumo expandido. Campinas.

Middlemost, E. A. K. (1985). Magmas and Magmatic Rocks: an Introduction to Igneous Petrology. Londres e Nova York: Longman, p. 253-257.

Nachit, H., Ibhi, A., Abia, E. H., Ohoud, M. B. (2005). Discrimination between primary magmatic biotites, reequilibrated and neoformed biotites. Comptes Rendus Geoscience, 337(16), 1415-1420. https://doi.org/10.1016/j. crte.2005.09.002

Nachit, H., Razafimahefa, N., Stussi, J. M., Carron, J. P. (1985). Composition chimiquedes biotites et typologie magmatiquedes granitoides. Comptes Rendus deI'Académie des Sciences Paris, 301, 813-818.

Nakamura, N. (1974). Determination of RRE, Ba, Fe, $\mathrm{Mg}, \mathrm{Na}$ and $\mathrm{K}$ in carbonaceus and ordinary chondrites. Geochimica et Cosmochimica Acta, 38(5), 757-775. https:// doi.org/10.1016/0016-7037(74)90149-5

Naney, M. T. (1983). Phase equilibria of rock-forming ferromagnesian silicates in granitic systems. American Journal of Sciences, 283(10), 993-1033. https://doi.org/10.2475/ ajs.283.10.993

Neves, S. P., Silva, J. M. R., Bruguier, O. (2016). The transition zone between the Pernambuco-Alagoas Domain and the Sergipano belt (Borborema Province, NE Brasil): Geochronological constraints on the ages of deposition, tectonic setting and metamorphism of metasedimentary rocks. Journal of South American Earth Sciences, 72, 266278. https://doi.org/10.1016/j.jsames.2016.09.010

Oliveira, D. B. (2016). Aspectos Geológicos, Petrográficos e Geoquímicos do Stock Serra da Vaca, Sistema Orogênico Sergipano. Trabalho de Conclusão de Curso. São Cristóvão: Universidade Federal de Sergipe. 
Oliveira, E. P., Bueno, J. F., McNaughton, N. J., Silva Filho, A. F., Nascimento, R. S., Donatti-Filho, J. P. (2015). Age, composition, and source of continental arc- and syn-collision granites of the Neoproterozoic Sergipano Belt, Southern Borborema Province, Brazil. Journal of South American Earth Sciences, 58, 257-280. https://doi.org/10.1016/j. jsames.2014.08.003

Oliveira, E. P., Windley, B. F., Araújo, M. N. C. (2010). The Neoproterozoic Sergipano orogenic belt, NE Brazil: a complete plate tectonic cycle in western Gondwana. Precambrian Research, 181(1-4), 64-84. https://doi. org/10.1016/j.precamres.2010.05.014

Oliveira, E. P., Windley, B. F., McNaughton, N. J., Bueno, J. F., Nascimento, R. S., Carvalho, M. J., Araújo, M. N. C. (2017). The Sergipano Belt. In: M. Heilbron, U. Cordani, F. Alkmim (Eds.), São Francisco Craton, Eastern Brazil. Regional Geology Reviews. Cham: Springer. https://doi. org/10.1007/978-3-319-01715-0_13

Pearce, J. A. (1996). Source and settings of Granites rocks. Episodes, 19(4), 120-125. https://doi.org/10.18814/ epiiugs/1996/v19i4/005

Pearce, J. A., Harris, N. B. W., Tindle, A. G. (1984). Trace element discrimination diagrams for the tectonic interpretation of granitic rocks. Journal of Petrology, 25(4), 956-983. https://doi.org/10.1093/petrology/25.4.956

Peccerillo, A., Taylor, S. R. (1976). Geochemistry of Eocene Calc-Alkaline Volcanic Rocks form the Kastamonu Area, Northen Turkey. Contribution Mineralogy Petrology, 58, 63-81. https://doi.org/10.1007/BF00384745

Pinho Neto, M. A., Rosa, M. L. S., Conceição, H. (2019). Petrologia do Batólito Sítios Novos, Sistema Orogênico Sergipano, Província Borborema, NE do Brasil. Geologia USP. Série Cientifica, 19(2), 135-150. https://doi.org/10.11606/ issn.2316-9095.v19-152469

Santos, I. S., Conceição, H., Rosa, M. L. S., Marinho, M. M. (2019). Magmatismos shoshonítico e cálcio-alcalino de alto potássio (615 Ma) na porção leste do Domínio Macururé, Sistema Orogênico Sergipano: Stocks Propriá, Amparo do São Francisco e Fazenda Alvorada. Geologia USP. Série Cientifica, 19(1), 99-116. https://doi.org/10.11606/issn.23169095.v19-141362

Santos, R. A., Martins, A. A. M., Neves, J. P., Leal, R. A. (1998). Programa de Levantamentos Geológicos Básicos do Brasil: Geologia e Recursos Minerais do Estado de Sergipe. Escala 1:250.000. Texto explicativo do mapa geológico do Estado de Sergipe. Salvador: CPRM/DIEDIG/ DEPAT; CODISE.

Santos, R. A., Menezes Filho, N. R., Souza, J. D. (1988). Programa de Levantamentos Geológicos Básicos do Brasil: carta geológica, carta metalogenética/previsional - Escala 1:100.00 (Folha SC.24-X-C-VI Piranhas). Sergipe, Alagoas e Bahia: DNPM/CPRM, 154 p.

Schmidt, M. W., Thompson, A. B. (1996). Epidote in calcalkaline magmas: an experimental study of stability, phase relationships, and the role of epidote in Magmatic evolution. American Mineralogist, 81(3-4), 462-474. https://doi. org/10.2138/am-1996-3-420

Sial, A. N. (1990). Epidote-bearing calc-alkaline granitoids in Northeast Brazil. Revista Brasileira de Geociências, 20(1-4), 88-100.

Sial, A. N., Ferreira, V. P. (2016). Magma associations in Ediacaran granitoids of the Cachoeirinha-Salgueiro and Alto Pajéu terrane, northeastern Brazil: Forty years of studies. Journal of South American Earth Sciences, 68, 113-133. https://doi.org/10.1016/j.jsames.2015.10.005

Silva Filho, M. A., Bomfim, L. F. C., Santos, R. A., Leal, R. A., Santana, A. C., Filho, P. A. B. (1979). Geologia da Geossinclinal Sergipana e do seu embasamento - Alagoas, Sergipe e Bahia: Projeto Baixo São Francisco/Vaza-Barris. Brasília: DNPM/CPRM.

Soares, H. S., Sousa, C. S., Conceição, H., Rosa, M. L. S. (2018). Caracterização Geológica, Petrográfica e Geoquímica dos Stocks Santa Maria e Monte Pedral, Domínio Canindé, Sistema Orogênico Sergipano. Scientia Plena, 14(1), 1-12. https://doi.org/10.14808/sci.plena.2018.015301

Soares, H. S., Sousa, C. S., Rosa, M. L. S., Conceição, H. (2019). Petrologia dos Stocks Santa Maria, Monte Pedral, Bom Jardim, Boa Esperança e Niterói, Suíte Intrusiva Serra do Catu, Estado de Sergipe, NE Brasil. Geologia USP. Série Cientifica, 19(4), 63-84. https://doi.org/10.11606/issn.2316-9095.v19-156598

Sousa, C. S., Soares, H. S., Rosa, M. L. S, Conceição, H. (2019). Petrologia e geocronologia do Batólito Rio Jacaré, Domínio Poço Redondo, Sistema Orogênico Sergipano, NE do Brasil. Geologia USP. Série Cientifica, 19(2), 171194. https://doi.org/10.11606/issn.2316-9095.v19-152494

Speer, J. A. (1984). Micas in igneous rocks. In: S. W. Bailey (ed.). Reviews in Mineralogy (v. 13, p. 299-356). Blacksburg: Mineralogical Society of America. https://doi. org/10.1515/9781501508820-013 
Streckeisen, A. L. (1976). To each plutonic rock its proper name. Earth Science Reviews, 12(1), 1-33. https://doi. org/10.1016/0012-8252(76)90052-0

Sylvester, P. J. (1989). Post-collisional alkaline granites. Journal of Geology, 97(3), 261-280. Disponível em: https:// www.jstor.org/stable/30068745. Acesso em: 7 maio 2021.

Teixeira, L. R., Lima, E. S., Neves, J. P., Santos, R. A., Santiago, R. C., Melo, R. C. (2014). Mapa Geológico e de Recursos Minerais do Estado de Sergipe. Escala 1:250.000. Aracaju: CPRM-CODISE.

Thompson, R. N. (1982). Magmatism of the British Tertiary volcanic Province. Scottish Journal of Geology, 18, 49-107. https://doi.org/10.1144/sjg18010049

Tulloch, A. J. (1979). Secondary Ca-Al silicates as lowgrade alteration products of granitoid biotite. Contribuitions to Mineralogy and Petrology, 69(2), 105-117. https://doi. org/10.1007/BF00371854
Van Schmus, W. R., Oliveira, E. P., Silva Filho, A., Toteu, S. F., Penaye, J., Guimarães, I. P. (2008). Proterozoic Links between the Borborema Province NE Brazil and the Central African Fold Belt. Geological Society London Special Publication, 294, 69-99. https://doi.org/10.1144/SP294.5

Van Schmus, W. R., Kozuch, M., Brito Neves, B. B. (2011). Precambrian history of the Zona Transversal of the Borborema Province, NE Brazil: Insights from Sm-Nd and U-Pb geochronology. Journal of South American Earth Sciences, 31(2-3), 227-252. https://doi.org/10.1016/j. jsames.2011.02.010

Wones, D. R. (1989). Significance of the assemblage titanite + magnetite + quartz in granitic rocks. American Mineralogist, 74(7-8), 744-749.

Zen, E.-A., Hammarstrom, J. M. (1984). Magmatic epidote and its petrologic significance. Geology, 12(9), 515-518. https://doi.org/10.1130/0091-7613(1984)12<515:MEAIP $\mathrm{S}>2.0 . \mathrm{CO} ; 2$ 